\title{
Ainda faz sentido discutir políticas públicas sob a perspectiva das regiões? Os desafios do Plano "Brasil sem Miséria"
}

\author{
RESUMO
}

Tuany Baron de Vargas

tuanybaron@gmil.com

(nencias Sociales, Buenos Aires, Argentina.
O debate acerca das regiões nacionais tem sido tangencial nos estudos desenvolvimentistas brasileiros. Tendo isso em vista, o objetivo central do presente estudo é a instrumentalização do conceito de região para a implementação de políticas públicas que visem a superação das desigualdades econômicas e sociais de maneira igualitária. Para tanto, buscou-se, mediante análise sistemática do Plano «Brasil sem Miséria», verificar de que modo se dá a articulação interfederativa nesse campo e se as características regionais são postas como relevantes. A partir de tal análise verificou-se que, a despeito de todos os méritos, o Plano foi insuficiente na definição de critérios de escolha de áreas prioritárias para atuação em cada frente, tornando-se ineficiente na proteção e proteção dos direitos mais básicos. Tendo isso em vista, concluiu-se pela necessidade da abertura da leitura jurídica à interdisciplinaridade como estratégia epistemológica, fazendo com que, finalmente, se possa começar a trilhar os caminhos da concretização da Constituição.

PALAVRAS-CHAVE: desenvolvimento regional; políticas públicas; Brasil Sem Miséria; direitos sociais; mínimo existencial. 


\section{POLÍTICAS PÚBLICAS DE DESENVOLVIMENTO REGIONAL E DIREITOS} FUNDAMENTIAS SOCIAIS: ALGUNS PRESSUPOSTOS

Como marco de um recomeço, a Constituição de 1988 surgiu como "uma resposta para o passado e uma proposta para o futuro" (CLÈVE, 2012, p. 41), seguindo a tendência do constitucionalismo emergente na segunda metade do século XX. As Constituições democráticas e/ou pluralistas deram especial atenção aos tão frágeis e necessários direitos sociais, elevando-os, inclusive, como é o caso da Constituição brasileira de 1988, ao status de direitos jusfundamentais. Logo, tais Cartas privilegiaram os direitos da pessoa, visando não só assegurar sua liberdade, como também assegurar-lhe condições materiais de sobrevivência. A partir desse novo paradigma, "a liberdade é a liberdade-autonomia do homem perante os outros homens e perante o Estado, é a liberdade-participação no Governo e na Administração, mas é também a liberdade-libertação da miséria, da insegurança, e da necessidade" (MIRANDA, 1976).

"A experiência política e constitucional do Brasil, da independência até 1988, é a melancólica história do desencontro de um país com a sua gente" (BARROSO; BARCELLOS, 2008, p. 327-328). As Constituições brasileiras, até então, traduziamse na materialização dos desejos das elites dominantes, a partir de noções essencialmente patrimonialistas, focadas na estrutura estatal necessária a consagrar tais aspirações. Foram identificadas, portanto, "por promessas de atuação e pretensos direitos que jamais se consumaram na prática. Uma história marcada pela insinceridade e pela frustração" (BARROSO; BARCELLOS, 2008, p. 328).

Embora o modelo do Estado de Bem-Estar social tenha variações quanto à sua inspiração providencialista nas experiências constitucionais mundiais, indubitavelmente o intervencionismo estatal é determinante em sua caracterização (OLIVEIRA, 2009). Na ordem constitucional que foi desenhada para o pós-88, o Estado recebeu o papel de principal promotor do desenvolvimento.

Nesse contexto, uma política desenvolvimentista calcada estritamente em seu sentido econômico está fadada ao fracasso, uma vez que outros elementos (sejam sociais ou políticos) são indissociáveis da própria existência do desenvolvimento, ou, ao menos, de um desenvolvimento minimamente sustentável ${ }^{1}$.

O Programa das Nações Unidas para o Desenvolvimento (PNUD), que desde 2000 fomenta o comprometimento e a discussão em prol do alcance dos Objetivos de Desenvolvimento do Milênio, aponta a erradicação da pobreza como indispensável ao desenvolvimento, colocando-o desde o início dos debates como o "primeiro" objetivo do milênio".

O documento final da Conferência das Nações Unidas sobre Desenvolvimento Sustentável - Rio+20, levando em consideração os resultados dos Objetivos de Desenvolvimento do Milênio traçou uma nova agenda, não somente com novas metas, mas também tendo em conta os objetivos não alcançados no antigo projeto. "Acabar com a pobreza em todas as suas formas, em todos os lugares", ainda está no topo da lista.

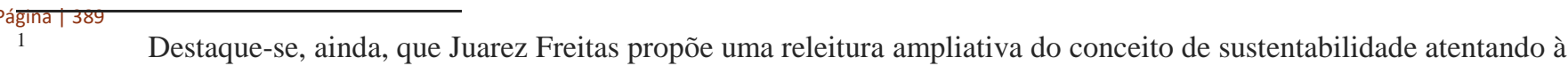
sua pluridimensionalidade, ou seja, para além do desenvolvimento econômico-social-político. (FREITAS, 2012, p. 56).
} 
Porém, a exigência de uma "liberdade-libertação da miséria" permanece sendo um desafio constante na experiência nacional. Embora a Constituição de 1967, em seu art. $8^{\circ}$, inciso XIII, tenha determinado, entre o rol de competências da União, o estabelecimento e a execução de "planos regionais de desenvolvimento", e incorporado o desenvolvimento econômico aos princípios da ordem econômica (disposições que permaneceram intactas com a reforma de 1969), foi apenas com a Constituição de 1988 que o direito fundamental ao desenvolvimento emergiu como uma forma de síntese dos direitos humanos, reforçando todas as suas promessas e dimensões, propugnando a todos os padrões de existência minimamente dignos (FACHIN, 2015, p. 219).

Se essa foi uma conquista atingida no plano do dever-ser pelo "ingresso do povo na trajetória política brasileira, como protagonista do processo, ao lado da velha aristocracia e da burguesia emergente" (BARROSO; BARCELLOS, 2008, p. 329), ao mesmo tempo, no plano do ser, a ideia de uma Constituição meramente diretiva não permitiu, em absoluto, a saída real da situação de pobreza pela maioria dos brasileiros.

Além disso, "o processo de desenvolvimento, que é desigual e combinado, no caso brasileiro, é agravado pela 'herança regional', determinada pela nossa evolução histórica" (BERCOVICI, 2003, p. 62). As dimensões territoriais do Brasil; a ocupação irregular de seu território; a diversidade social; a diversidade de sistemas econômicos regionais desenvolvidos a partir de suas múltiplas potencialidades ${ }^{2}$; e os processos de consolidação, declínio ou transformação dessas economias; constituíram, certamente, um campo propício para o surgimento de agudas "questões regionais".

No estudo da pobreza e das suas origens, diversos debates são travados acerca de sua própria definição. Porém, a despeito dessa ausência de consenso, todas as abordagens afastam a redução da questão à insuficiência de renda. Todas as correntes consoam no sentido de admitir as mais diversas formas em que se manifestam a pobreza. A população nessa situação, em geral, também sofre de insegurança alimentar e nutricional, tem baixa escolaridade e pouca qualificação profissional, encontram-se em situação de fragilidade em relação à sua inserção no mercado de trabalho, tem acesso precário à água, energia elétrica, serviços de saúde, moradia, entre outras privações (BRASIL, 2014, p. 130). Ou seja, sua erradicação (essencial à efetivação do direito ao desenvolvimento) demanda o fornecimento de serviços públicos de maneira indispensável.

Sobretudo até a metade do século XX, a oferta pública de serviços centravase nas regiões Sul e Sudeste. "Grande parte da população que vivia acima do paralelo 20 simplesmente não contava com acesso a redes de água, esgoto e energia elétrica. Mesmo indivíduos de renda média e (até) alta não contavam com a oferta pública desses serviços" (ARRETCHE, 2015, p. 197).

A Administração Pública brasileira encontrava-se (e ainda se encontra) em uma distância considerável das exigências do desenvolvimento. Sem

2 Destaque à tradicional periodização da história econômica brasileira a partir dos "ciclos" de produtos voltados para a exportação, v.g., cite-se, a economia escravista de agricultura tropical (com destaque ao "complexo econômico nordestino" e Pág̀n posteriormente, para o sistema industrial) e a articulação comercial e da estrutura produtiva da economia da Amazônia e do Centro-Oeste do país. (FURTADO, 2007) 
desconsiderar todos os esforços doutrinários que cercam a questão, por meio de uma organização tradicional - em que mudanças geralmente foram introduzidas de maneira improvisada -, a mentalidade por trás do aparelhamento de Estado mostra-se inapta para a promoção do desenvolvimento. Voltada a um modelo ainda essencialmente liberal de proteção de direitos individuais face ao Estado, muitas vezes, a Administração (e o Direito Administrativo) não está preparada para a implementação dos princípios, dos direitos e das políticas consagradas pela Constituição (BERCOVICI, 2005).

\section{CONTORNOS JURÍDICOS DAS POLÍTICAS PÚBLICAS: A NECESSÁRIA ABERTURA À INTERDISCIPLINARIDADE}

Não é possível considerar a existência de um conceito unicamente jurídico de políticas públicas, inclusive pela dificuldade do Direito em apreender seu fenômeno por completo. Aguilar Villanueva destaca as multifacetas que podem denotar a expressão políticas: campo de atividade governamental, propósito público a ser realizado, situação social desejada, propostas de ação, normas destinadas a solucionar determinado problema, objetivos e programas de ação governamentais em um campo determinado, produto e resultado de uma atividade governamental, o impacto real da atividade governamental, ou, ainda, o modelo teórico em que se sustenta uma política governamental. (AGUILAR VILLANUEVA, 1992, p. 22)

Dessa forma, é possível observar que as conceituações que se prestam aos juristas, nesse sentido, são apenas meios de compreensão e não categorias estruturantes propriamente ditas. Isso porque, para que se demonstrem tais categorias são necessárias, essencialmente, conceituações de outros ramos do saber, tais como Administração Pública e Ciência Política. Dessa forma, então, para que se defina o que vem a ser «políticas públicas» é indispensável uma abertura do direito à interdisciplinaridade. (BUCCl, 2006)

Até a década de 1990 o estudo do Estado se limitava, em muito, por análises macrossociológicas, dentre elas o Estado enquanto principal responsável pelo desenvolvimento econômico (MAQUES;FARIA, 2013, p. 7). O tema das políticas públicas somente passou a receber certa atenção dos juristas a partir de então. Somente a partir dos anos 90 é que houve, portanto, um crescente interesse dos juristas brasileiros pelo tema, sobretudo pela apreensão de uma mudança global no que tange às atribuições da Administração Pública, bem como com a internacionalização de temas que outrora eram discutidos apenas em âmbito doméstico, a crescente participação dos grupos de pressão nos processos decisórios, a necessidade de transparência e sua maior exigência, além da necessidade de informação em todas as áreas de ação governamental. (SARAIVA, 2006)

Outra dificuldade recorrente da análise jurídica do fenômeno das políticas públicas é a dificuldade de mapeá-las, de maneira clara e uniforme. Isso porque, estas não assumem padrões e seus processos podem ser exteriorizados através de disposições constitucionais, leis, decretos, regulamentos, portarias, circulares, instruções normativas e operacionais ou por meio de contratos administrativos. 
Assim, necessária se faz a delimitação do conceito de políticas, o qual pode ser identificado em três vertentes básicas: (i) política constitucional; (ii) política competitiva e (iii) política pública.

A política constitucional diz respeito à conformação básica de um Estado, o equivalente ao "polity»" da literatura dos países de língua inglesa. Essa política define os direitos fundamentais e impõe ao Estado deveres de proteção e prestação em relação a eles, bem como estabelece procedimentos e processos de tomada de decisão dos agentes públicos e assegura a participação popular. Dessa forma,

pode-se dizer que uma política constitucional é democrática em decorrência dos procedimentos que estabelece (quem governa e como governa). Por sua vez, uma política constitucional pode ser considerada social quando assegura aos governados direitos sociais mínimos de existência digna - embora se saiba que a definição de existência digna não é de fácil consenso. (FRANCO, MONTEMEZZO, 2016, p. 103)

A segunda concepção do termo recebe o enfoque dos atores políticos ou das atividades de conflito, alianças e etc. Designada pelo termo "politics». É a partir dessa vertente que se delineia a condução do agir governamental. Numa democracia, a política competitiva não só é legítima como é desejável e essencial.

Por último temos as políticas públicas enquanto produto da atividade política do Estado. $O$ equivalente à expressão «policies». Estas condicionadas tanto pelas «politics» quanto pela «polity».

A política constitucional é responsável pela definição de dois aspectos fundamentais: (i) o espaço no qual a competição política poderá se desenvolver e (ii) os conteúdos legítimos das políticas públicas concretizadas como um desfecho do jogo político. (COUTO, 2005, p. 96)

Embora vulgarmente apenas a concepção de política competitiva seja relacionada ao exercício de poder social, em todas as suas vertentes ela assim se identifica. A política competitiva torna-se mais evidente por relacionar-se ao embate político de ideias na arena pública. Porém sé no âmbito das políticas públicas que se apresentam as soluções de manejo dos assuntos públicos e se definem planos de ação. Política competitiva e política pública são independentes entre si, porém suas existências de forma isolada são impactantes no exercício da democracia e geram seu enfraquecimento. O exercício demagógico do poder decorre da "politcs» sem as "policies». Ao passo que as policies sem o devido embate de ideias debilitam a governabilidade social. (PARADA, 2006, p. 68)

Bem por isso, Dowrkin (1978) ao tratar do tema, denomina, portanto, "policy» como um tipo de padrão (ou norma) que estabelece que determinado objetivo deva ser alcançado, consistindo, por exemplo, em uma melhoria social, econômica ou política para a comunidade. Tais diretrizes, por outro lado, não pretendem regular um comportamento específico, atribuindo-lhe qualidade. "Policies» visam alcance de um estado de coisas que pressupõe consenso e decisões estratégicas para sua concretização.

Veja-se que nos Estados Unidos da América os juristas optaram por uma definição não jurídica para lidar com o tema. «Políticas Públicas», para eles,

3 Certa confusão pode ser extraída de algumas traduções da literatura norte-americana. 
representam um princípio de que nenhuma pessoa ou autoridade do governo pode legalmente realizar um ato que tende a prejudicar o público. Ela manifesta a consciência comum dos cidadãos, que se estende por todo o Estado e é aplicado a questões de saúde pública, segurança e bem-estar. Revelam-se em função da evolução das necessidades econômicas, costumes sociais e aspirações morais do povo. A política pública influencia a promulgação, execução e interpretação da legislação. (LEHMAN; PHELPS, 2008)

Políticas públicas podem ser expressas em instrumentos normativos ou contratuais, que conformaram a atividade estatal a partir de processos juridicamente articulados voltados à contemplação dos interesses de toda a coletividade. Através da ampla interação deste conjunto de processos - eleitoral, de planejamento, de governo, orçamentário, legislativo, administrativo, judicial e que por certo se organizam também a partir da pluralidade de influências, busca-se coordenar os meios à disposição do Estado para a realização de objetivos socialmente relevantes e politicamente determinados. (BUCCl, 2006, p. 37-39)

Há também um aspecto processual interno que pode ser percebido no delineamento das políticas públicas. Trata-se de etapas que consubstanciam o chamado ciclo de políticas públicas, e que, segundo a doutrina, diz respeito aos diversos eixos de desenvolvimento de ideias e problemas em tomada de decisão e implementação da atuação estatal. Em todas estas etapas - identificação do problema, formação de agenda, formulação de alternativas, tomada de decisões, implementação e avaliação - certamente há a influência de diversos agentes na conformação das ações, sejam atores políticos ou agentes institucionais competentes. (VALLE, 2009, p. 41)

Assim sendo, impossível a discussão de qualquer política pública de desenvolvimento, com foco principal na erradicação da miséria, a partir de uma visão meramente estruturalista, como tem sido orientado por literatura econômica e que, embora ultrapassada, ainda orienta o desenvolvimentismo nacional.

\section{O MÍNIMO EXISTENCIAL COMO REGRA E PRECEITO ÉTICO DA ATUAÇÃO ESTATAL}

O mínimo existencial tem papel importante em toda a História Fiscal da modernidade. No Estado Patrimonial havia uma estrutura impositiva essencialmente injusta, atentatória à dignidade do homem e permanentemente deficitária, pelo grande aporte da carga tributária suportada pela população carente. Já no Estado de Polícia a população que não obtinha recursos mínimos para garantir sua sobrevivência passou a ser beneficiária de imunidades tributárias. No Brasil, com o advento da Constituição de 1824, é perceptível, especialmente no art. 179, características de um Estado Fiscal de Direito, em que se garante assistência social gratuita a despeito de contraprestações pecuniárias do cidadão. Com o Estado Social Fiscal percebe-se que as políticas são executadas por mecanismos paternalistas a partir de uma adoção das noções de justiça social (TORRES, 1991). Atualmente, sob a égide do Estado Democrático de Direito a análise do mínimo existencial deve feita a partir das lentes dos direitos humanos e do(s) constitucionalismo(s). 
A conformação do Estado Democrático de Direito, consagrado pelo art. 1ㅇ da Constituição Federal de 1988, implica na síntese das noções de Constitucionalismo (Estado de direito, ruleoflaw, Rechtsstaat) e de Democracia. Entretanto, essa junção pode, por vezes, implicar em pontos de tensão na medida em que certas circunstancias carecem que a vontade majoritária se detenha diante de determinados conteúdos materiais, orgânicos ou processuais da Constituição. (BARROSO, 2007)

Esse desenho de Estado importa em sua gravitação em torno da dignidade da pessoa humana e dos direitos fundamentais que incluem a liberdade, a igualdade e o mínimo existencial, sendo esse último compreendido pelas "condições elementares de educação, saúde e renda que permitam, em uma determinada sociedade, o acesso aos valores civilizatórios e a participação esclarecida no processo político e no debate público" (BARROSO, 2007).

A apreensão da normatividade da Constituição estabeleceu novos patamares ao constitucionalismo brasileiro e possibilitou uma guinada jurisprudencial, influenciada fortemente pela chamada doutrina brasileira da efetividade.

A dignidade da pessoa humana tem origem secular na filosofia ${ }^{4}$, sendo comumente relacionada com um valor intrínseco a todo indivíduo que gera a capacidade de se autodeterminar, fazendo as escolhas morais necessárias ao seu bem-estar. Com o reconhecimento da importância da dignidade para a proteção dos indivíduos face ao Estado - bem como em relação a outros indivíduos -, a partir da metade do século XX, esse princípio, agora considerado base de todo o ordenamento jurídico passou a ser positivado constitucionalmente, funcionando como verdadeira fonte de direitos e, consequentemente, de deveres.

Diante da falta de um documento, seja ele nacional ou internacional, que efetivamente defina o termo "dignidade da pessoa humana», se faz necessário estabelecer um conteúdo mínimo, ou núcleo essencial, para o princípio. Nesse sentido, afirma Barroso ser a dignidade um conceito multifacetado, cuja interpretação, realizada em uma escala minimalista, nos revela três facetas: a) a dignidade como valor intrínseco ao ser humano; b) a dignidade como expressão da autonomia do indivíduo; e c) a dignidade como "valor comunitário", gerando a possibilidade de limitação de direitos individuais visando a proteção de interesses coletivos (BARROSO, 2012, p. 61-98). Para alcançar a temática aqui abordada, focar-se-á especialmente no segundo aspecto: a dignidade como autonomia.

Nessa perspectiva, a dignidade está intimamente ligada a um conjunto de direitos fundamentais, que incluem desde as liberdades básicas, até os direitos sociais. Integra o núcleo essencial desse princípio, portanto, o mínimo existencial, ou o direito básico às provisões necessárias para que se viva dignamente ${ }^{5}$. Assim sendo, para que haja autonomia, e a capacidade de autodeterminação intrínseca à dignidade da pessoa humana, é necessário que o indivíduo não só seja livre, mas também seja livre de necessidades, estando satisfeitas as suas necessidades vitais essenciais. Daí extrai-se a responsabilidade do Estado na garantia dos demais direitos necessários à vida digna de seus cidadãos, sejam eles individuais ou transindividuais.

${ }^{4}$ A filosofia Kantiana, desde seus primórdios, já afirmava o homem, ser racional que é, existe não como meio, mas como fim Páên siomesmo, devendo assim ser respeitado como tal.

${ }^{5}$ Adota-se no presente trabalho a delimitação de Ana Paula de Barcellos, que será tratada adiante, admitindo que o mínimo existencial se compõe pelo direito à educação básica, a saúde básica, ao auxílio aos desamparados e ao acesso à justiça. 
O reconhecimento do mínimo existencial pelo Tribunal Administrativo Federal alemão em 1954 é certamente marcante para a trajetória constitucional acerca desse tema. Embora o tema tenha sido proposto originalmente por Otto Bachof e desenvolvido a partir da conjugação do princípio da dignidade da pessoa humana, da cláusula do Estado Social e dos direitos à liberdade e à vida, Daniel Sarmento identifica na doutrina de Pontes de Miranda, na década de 1930, a primeira formulação jurídica sobre o tema. (SARMENTO, 2016. p. 191-192)

\begin{abstract}
Como direito público subjetivo, a subsistência realiza, no terreno da alimentação, das vestes e da habitação, o standartof living segundo três números variáveis para maior indefinidademente e para menor até o limite, limite que é dado, respectivamente, como indispensável à vida quanto à nutrição, resguardo do corpo e à instalação. É o mínimo vital absoluto. Sempre, porém, que nos referimos ao mínimo vital, deve-se entender o mínimo vital relativo, aquele que, atentando-se às circunstâncias de lugar e de tempo, se fixou para cada zona em determinado período. O mínimo vital relativo tem de ser igual ou maior que $\mathrm{o}$ absoluto. $\mathrm{O}$ direito à subsistência torna sem razão de ser a caridade, a esmola, a humilhação do homem pelo homem. Não se peça a outrem, porque falte; exija-se do Estado, porque êste deve. Em vez de súplica, o direito. (MIRANDA, 1933, p. 28)
\end{abstract}

A doutrina jurídica atual não estabelece maiores ressalvas acerca do acolhimento e proteção do mínimo existencial pela Constituição, e o mesmo vem ocorrendo com a jurisprudência, sobretudo a partir do julgamento da Arguição de Descumprimento de Preceito Fundamental no 45 pelo Supremo Tribunal Federal. A maior dificuldade encontrada pela doutrina jurídica é quanto à forma de aplicação do mínimo existencial e implicará na adoção da teoria do mínimo existencial prima facie ou da teoria do mínimo existencial definitivo.

Ronald Dworkin afirma que embora algumas regras e princípios possam ter funções bastantes semelhantes na prática, implicando, muitas vezes, que do ponto de vista lógico funcionem como regra e do ponto de vista substantivo como princípios (dependendo de critérios, princípios e políticas que extrapolam seu conteúdo), não faz com que tornem-se princípios.

"A utilização desses termos faz com que essa regra se assemelhe mais a um princípio. Mas não chega a transformar a regra em princípio, pois até mesmo o menos restritivo desses termos restringe o tipo de princípios e políticas dos quais pode depender a regra" (DWORKIN, 1978, p. 45). Sob essa perspectiva que o mínimo existencial deve ser lido da seguinte forma: encontrando-se no campo da validade, como um mandamento definitivo que deverá ser aplicado sob a lógica do "tudo ou nada".

Note-se que ao se admitir a teoria do mínimo existencial prima faciese parte de uma premissa tautológica: se o mínimo existencial é o núcleo da Dignidade da Pessoa Humana, e se considerado como um princípio, admitindo que seja ponderado no caso concreto, o que se está a fazer, em verdade, é a ponderação do próprio princípio da Dignidade da Pessoa Humana. Dessa forma, a própria existência da noção de mínimo existencial seria desnecessária e irrelevante.

Dessa forma, os adeptos dessa teoria consideram que a ponderação já foi realizada pelo constituinte, ao vincular o mínimo existencial como elemento essencial à proteção da Dignidade da Pessoa Humana. Partindo desse ponto, a 
intenção do constituinte era de que o mínimo existencial sempre estivesse inserido na capacidade orçamentária, e sendo assim, a sua aplicação direta não poderia sucumbir diante de argumentos como o da reserva do possível.

Essa perspectiva parece ser a mais lógica, como também a mais adequada, sobretudo porque o mínimo existencial apresenta-se como o núcleo da dignidade da pessoa humana, e não pode ser admitido que seja afastado quando em conflito com outros princípios.

É interessante destacar que até os postulados da justiça libertária, que coloca os direitos de liberdade como principal objetivo da busca de bem-estar social (SOUZA; COSTA, 2014), preocupa-se com o substrato material mínimo da dignidade da pessoa humana. Ao formular os princípios de justiça John Rawls, com vista em uma sociedade bem-ordenada e cooperativa, destina grande preocupação em relação à satisfação de necessidades básicas dos cidadãos como pré-requisito para o exercício de liberdades básicas.

Embora o autor considere o "princípio da liberdade igual" como primeiro princípio de justiça, afirma, explicitamente, que tal princípio deve

\begin{abstract}
ser precedido de um princípio lexicamente anterior, que prescreva a satisfação das necessidades básicas dos cidadãos, ao menos à medida que a satisfação dessas necessidades seja necessária para que os cidadãos entendam e tenham condições de exercer de forma fecunda esses direitos e liberdades. (RAWLS, 2005, p. 27)
\end{abstract}

Portanto, estabelece condições prévias para o exercício dos direitos fundamentais de liberdade. Rawls considera que tal condição está pressuposta no primeiro princípio de justiça, sendo o mínimo existencial um elemento constitucional essencial. Uma concepção de justiça dever incluir um mínimo existencial na formulação de seus princípios, sobretudo quando trata da garantia e promoção dos direitos fundamentais e de seu fundamento, a dignidade humana. "Também quando se refere à extensão de um consenso constitucional, Rawls insiste em mostrar que na sua concepção política de justiça, a satisfação das necessidades básicas dos cidadãos é elemento constitucional essencial" (WEBER, 2013). Ademais, merece ser destacado que o mínimo existencial pode também ser reportado ao segundo princípio, "da diferença», que se aplica à distribuição de renda e riqueza, onde, com a devida contextualização, a distribuição dos bens sociais deve ser justificada frente aos menos favorecidos. Assim, o mínimo existencial estará muito próximo do que Rawls define por bens primários: "a dimensão do que é necessário para que os cidadãos como livres e iguais tenham uma vida digna. Trata-se de condições sociais e meios polivalentes geralmente necessários para que os cidadãos possam desenvolver-se adequadamente" (WEBER, 2013).

Entretanto, a despeito de toda construção de teóricos da justiça ou da teoria constitucional, além de alguns avanços práticos nessa matéria, os direitos fundamentais sociais (inclusive os que garantem o mínimo existencial) ainda são colocados como entraves à atuação estatal, sobretudo porque são apresentados, por diversos doutrinadores, tal como Virgílio Afonso da Silva, como direitos que tem um custo monetário maior ao Estado. Embora não se possa negar a relevância econômica desses direitos, compartilha-se o entendimento de Sarlet para afirmar que todos os direitos fundamentais têm custos, porém 
se a regra da relevância econômica dos direitos sociais prestacionais pode ser aceita sem maiores reservas, há que se questionar, todavia, se efetivamente todos os direitos dessa natureza apresentam dimensão econômica, havendo, nesse contexto, quem sustente a existência de exceções, apontando para os direitos sociais a prestações economicamente neutros [...], no sentido de que há prestações materiais condicionadas ao pagamento de taxas e tarifas públicas, além de outras que se restringem ao acesso de recursos já disponíveis. (SARLET, 2012, p. 286)

O autor sustenta, então, que mesmo que nesses casos haveria repercussão econômica, ainda que indireta, uma vez que esses recursos já existentes necessariamente foram realocados para garantir os direitos fundamentais sociais, recursos esses oriundos da receita tributária e de outras formas de arrecadação.

Ademais, frise-se que, se tomada como ponto de partida os pressupostos da teoria da justiça de John Rawls, se pode afirmar que o mínimo existencial é assegurando pelos suplementos de renda, e sendo assim, no âmbito dos entes subnacionais, protegido pelas transferências orçamentárias (TORRES, 2008, p. 365).

Há um cuidado, porém, que deve ser tomado. O mínimo existencial não é mero pressuposto para a fruição de outros direitos. Parece claro, na construção da teoria da justiça de Rawls, adotada no presente trabalho, que a satisfação de necessidades materiais básicos é um componente central da ideia de justiça, sendo por si só uma justificativa suficiente para a sua proteção jurídica, e, sobretudo, constitucional.

Por outro lado, "a garantia do mínimo existencial é importante para a proteção e promoção da liberdade e da democracia, mas mesmo em hipóteses em que tais princípios não estejam em jogo, as condições materiais básicas de vida devem ser asseguradas" (SARMENTO, 2016, p. 208). Bem por isso é que não se pode perder de vista que o mínimo existencial é sim um instrumento para que se alcacem outros fins, mas não é digno de proteção apenas por isso. Sua proteção é autônoma em relação a quaisquer outros direitos.

\begin{abstract}
A dependência do mínimo existencial em relação aos direitos civis e políticos parece derivar de uma indevida hierarquização entre esses direitos e os sociais. Mesmo autores situados no campo progressista, como Rawls e Habermas, ao tratarem da questão, parecem incorrer no velho cacoete do liberalismo-burguês de desvalorizar os direitos sociais em face dos individuais e políticos. Porém, além de não se sustentar sob o ângulo de uma moral crítica, no Brasil, essa concepção não encontra qualquer amparo, seja no ordenamento constitucional vigente, que não contempla hierarquia dessa natureza, sejana nossa cultura social. Nosso ethos, inclusive, parece apontar até no sentido oposto, da prioridade dos direitos sociais em face das liberdades, o que não deixa de ser igualmente problemático. (SARMENTO, 2016, p. 209)
\end{abstract}

Na doutrina nacional, Ricardo Lobo Torres é um dos principais autores que cuidam de tal temática. Entretanto, por sua vez, distingue o mínimo existencial dos direitos sociais. Os direitos sociais seriam fruto de normas programáticas com status constitucional e estas não se imiscuiriam com problemas econômicos 
29/2000, e no $31 / 2000^{6}$ levaram a uma confusão entre direitos sociais e mínimo existencial. O autor desconsidera os direitos sociais como genuínos direitos fundamentais que detêm aplicabilidade imediata, como geradores de efeitos distintos em relação aos direitos de liberdade, e afirma que a pretensão do cidadão, em relação aos direitos sociais, seria à política pública e não à adjudicação individual de bens públicos (TORRES, 2008, p. 428-430). Ou seja, para o autor, a atual postura tomada pelos Tribunais seria acertada apenas quando garantisse o mínimo existencial. Os direitos sociais, nessa visão, seriam apenas efetivados dentro da lógica da legalidade orçamentária, sob a lógica da reserva do possível e protegidos por mandado de injunção, quando carecedores de regulamentação.

Mesmo que tal concepção seja problemática ao desconsiderar a fundamentalidade dos direitos sociais, e mereça ressalvas no tocante à judicialização, coloca o campo das políticas públicas como campo principal de promoção desses direitos.

Quando a doutrina jurídica trata da proteção do mínimo existencial e da implementação dos direitos sociais e econômicos normalmente o faz para discutir os contornos da legitimidade da atuação judicial nesse campo, sobretudo para defender a menor judicialização da(s) política(s). A argumentação para tanto advém da concepção que a efetivação dos direitos fundamentais, que embora tenham força normativa, não pode ficar restrita aos cidadãos que têm acesso ao Poder Judiciário para pleiteá-los, ignorando que a "Reforma do Judiciário" em 2004 teve como um de seus principais propósitos a garantia da isonomia, sobretudo mediante instituição da repercussão geral no recurso extraordinário e da súmula vinculante. (HACHEM, 2013)

Ocorre que, com lastro nessa construção teórica alguns autores passaram a d efender que a jusfundamentalidade dos direitos sociais estaria restrita ao mínimo existencial, colocando os demais direitos sociais, que compõe o rol do art. 60 e os demais que assim possam ser considerados pela cláusula de abertura material da Constituição, à mercê do regime jurídico especial que recebem os direitos fundamentais e da aplicabilidade imediata que eles Ihe impõem.

O tema ganha relevância sob a ótica do Direito Administrativo pelo fato de que essa concepção minimalista a respeito da jusfundamentalidade dos direitos econômicos e sociais, [...] pode conduzir a outro raciocínio: o de que não apenas o Judiciário deve se limitar a conceder esse mínimo (como pretendia parcela da doutrina constitucionalista), mas também o Poder Executivo. Ou seja: poderia levar à afirmação de que o cidadão não poderia exigir da Administração a implementação de políticas públicas e a prestação de serviços públicos voltados à realização do conteúdo pleno de seus direitos fundamentais sociais, mas apenas o mínimo necessário para se viver dignamente. Salvaguardado esse ponto de partida, que permitiria uma igualdade de oportunidades a todos e o exercício de suas liberdades, cada indivíduo deveria lutar para conquistar melhores posições sociais, de sorte que, pelo critério do mérito, as desigualdades entre os mais ricos e os mais pobres seriam justas. $\mathrm{O}$ papel do Estado - e não apenas do Judiciário - se limitaria a

\footnotetext{
Páglna 1398 Essas Emendas Constitucionais vincularam a destinação parte do orçamento respectivamente à educação, à saúde e
} à erradicação da pobreza. 
assegurar o essencial para a garantia das liberdades. (HACHEM, 2013)

A preocupação levantada por Daniel WunderHachem é ainda mais evidente se levadas em conta as críticas contrárias à temática. Tais juízos afirmam que os cidadãos não deveriam satisfazer-se com migalhas: deveriam aspirar a justiça social de forma ampla e não se contentar com o pouco que o mínimo existencial garante. "Nessa perspectiva, há que associe o mínimo existencial a uma visão elitista e excludente, própria do neoliberalismo, que busca limitar a atuação do Estado do campo social e preservar a essência das estruturas econômicas do capitalismo" (SARMENTO, 2016, p. 209). Tal inquietação surge de uma necessidade de ser construir uma teoria adequada ao mínimo existencial que não corrobore a crítica aventada. Trata-se, pois, de tratar a temática com a contextualização constitucional adequada para que não opere "com os sinais trocados" com o objetivo de restringir a eficácia dos direitos sociais (SARMENTO, 2016, p. 210). Ou seja,

\begin{abstract}
O mínimo existencial não pode ser empregado para justificar genericamente a denegação de prestações materiais previstas na própria Lei Fundamental, mas que nele não se insiram - e.g., benefícios previdenciários superiores ao salário mínimo, 13ㅇ salário para trabalhadores e servidores públicos etc. Ele não permite que o intérprete se converta em uma espécie de censor conservador do poder constituinte com a faculdade de reformar in pejus a proteção social conferida expressamente pela própria Constituição para descartar ou negar eficácia a tudo àquilo que não repute tão essencial. (SARMENTO, 2016, p. 210).
\end{abstract}

Essa compreensão conservadora, quando trasladada para o Direito Administrativo, mostra-se presa à tendência do pensamento administrativista manifestada principalmente na segunda metade da década de 1990, que embora duramente criticada por parte da doutrina, logrou alterar a realidade normativa brasileira. Uma linha que propunha um papel subsidiário do Estado, tendo a inciativa privada parte das incumbências em termos de promoção de direitos e desenvolvimento. A função do Estado seria apenas de regulamentar e fomentar tais atividades. (HACHEM, 2013)

Ainda que tal corrente tenha logrado êxito em sua época, atualmente o Direito Administrativo recebe nova feição, uma feição eminentemente social, destinada a uma atuação estatal interventiva seja no domínio econômico, seja no domínio social, sobretudo tendo-se em vista a necessidade, cada vez mais urgente, do Estado Social e Democrático de Direito.

As significativas transformações empreendidas pelos governos, sobretudo a partir de 2003, mediante a instituição de programas sociais com vistas à garantia do mínimo existencial e a promoção de outros direitos sociais impactaram, não só politicamente, mas na visão das funções do Estado pela literatura jusadministrativista.

\title{
REGIONALISMO OU REGIONALIZAÇÃO
}

No Brasil atual não é mais possível a utilização dos complexos econômicos regionais autônomos para a discussão das regiões, sobretudo pela homogeneização das relações de produção no território. Por outro lado, "por 
mais que, hoje, seja comum a afirmação de que não existe mais a Questão Regional, apenas a Questão Nacional, deve-se levar em conta que todo problema nacional tem reflexos e condicionantes regionais, que exigem soluções diferenciadas" (BERCOVICl, 2003, p. 73) ${ }^{7}$.

"O que é surpreendente é que após a grande ilusão gerada pelas propostas de equilíbrio regional, não haja ainda um esforço consistente de avaliação da temática regional, como teoria e como política" (LENCIONI, 1992, p. 83).Ao contrário do que possa se pensar, em uma primeira análise, o objetivo de se estudar o desenvolvimento com foco na regionalização não se traduz na defesa de noções regionalistas. As reivindicações políticas (inclusive as de cunho econômico) de um grupo geograficamente localizado, como era o caso das Ligas Camponesas nas décadas de 1950 e 1960, frente ao Estado é o que se convenciona chamar de regionalismo.

O discurso regionalista e a criação de um "nordeste como região-problema" tradicionalmente foram utilizados por elites regionais dispostas a atrair para si investimentos sob o manto de um vitimismo circunstancial, um fatalismo isento de responsabilidades próprias. "Se tudo movem cordéis lá de cima, para que lutar, reagir? Deus quis" (LOBATO, 2007, p. 176). A venda das imagens dos Jecas Tatus e do "jeca-centrismo" trazem consigo, por óbvio, a desconfiança. "A forma predatória e oligárquica com que se criou o discurso regionalista no Nordeste acaba interferindo e prejudicando qualquer tentativa mais sólida e abrangente de reduzir, efetivamente, os desequilíbrios regionais e democratizar o desenvolvimento" (BERCOVICl, 2003, p. 78).

Por outro lado, pensar-se sob a perspectiva da regionalização significa "instrumentalizar o conceito de região para a implementação de políticas públicas que visem a superação das desigualdades econômicas e sociais. Ou seja, criar uma política de planejamento e ordenamento territorial mais adequada para promover o desenvolvimento" (BERCOVICl, 2003, p. 79).

"A regionalização imprimirá ao País feição mais livre, mais autêntica, mais criadora, mais humana e, sobretudo, mais nacional. O nacional, unido ao regional, constitui expressão humana e democrática da unidade, pelas vias do consenso e da legitimação" (BONAVIDES, 1993, p. 55).

Marta Arretche, ao analisar a temática regional, destaca que o Brasil mudou consideravelmente entre 1970 e 2010 no que diz respeito à oferta de serviços públicos essenciais. Entretanto, embora a oferta tenha aumentando nesse período, isso não implicou a universalização do acesso à esses serviços. Além disso, a distribuição territorial de sua provisão é fortemente desigual. (ARRETCHE, 2015)

Os quarenta anos compreendidos entre 1970 e 2010 apresentaram melora generalizada em todas as dimensões clássicas de bem-estar nos municípios brasileiros: renda, capital humano e capital físico. Entretanto, a desigualdade de riqueza, medida pelo PIB per capita, permaneceu rigorosa e escandalosamente estável, ao passo que aumentou a desigualdade territorial da concentração de pobres. (ARRETCHE, 2015, p. 196) ente federativo no modelo de Estado brasileiro. (BONAVIDES, 1993, p. 53-77). 
Ao contrário da visão estritamente economicista difundida nos anos 60 , e de posicionamentos defendidos pela literatura de matriz liberal na atualidade, com o advento da Constituição de 1988 conotação diversa deve ser dada ao sentido do desenvolvimento. A Constituição imprimiu uma feição intimamente ligada ao valor de igualdade, em que a redução das distâncias entre as posições ocupadas pelos cidadãos torna-se central (HACHEM, 2013)."A interdependência desta com a esfera humana e social é justamente um dos pontos cruciais do conceito, que o diferenciam da noção de crescimento" (HACHEM, 2013).

A elevação do produto nacional interno bruto reflete o "crescimento econômico". Esse é verificado, portanto, em termos meramente quantitativos. Mesmo levando em conta apenas esse dado, o Gráfico 1 demonstra que no período de 40 anos a desigualdade de PIB per capita caiu muito pouco, indo de 0,494 para 0,403 , enquanto o percentual de pobres cresceu consideravelmente.

GRÁFICO 1 - Coeficiente de Gini, PIB per capita e acesso a serviços essenciais - Municípios brasileiros, 1970-2010. (ARRETCHE, 2015, p. 199)

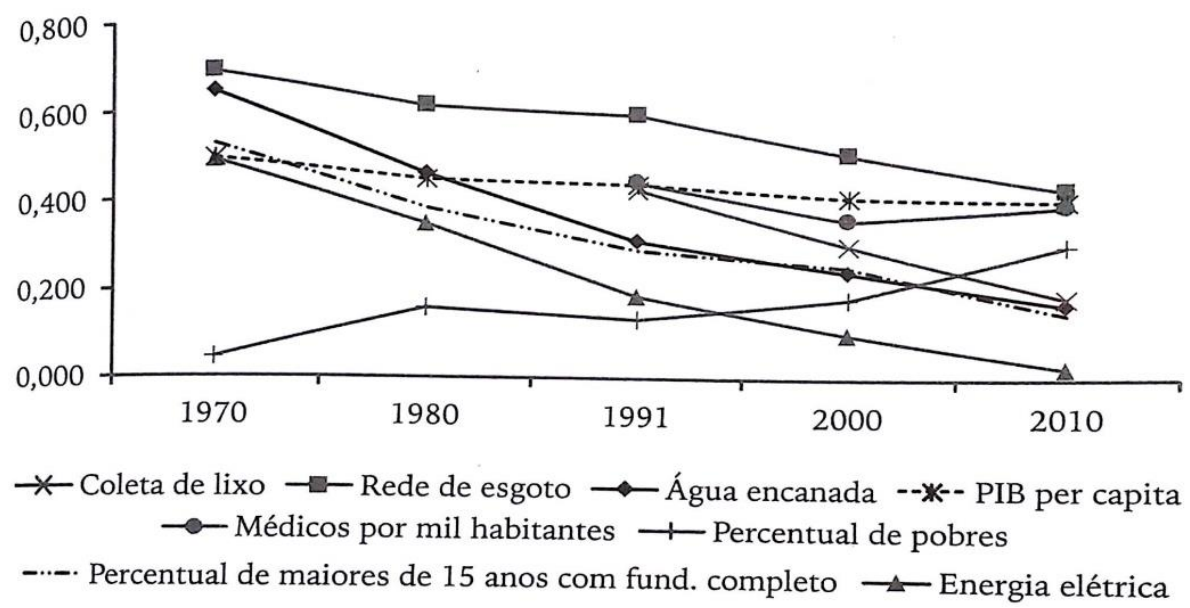

Ademais, Arretche em seus estudos destacou que a espantosa semelhança na desigualdade espacial de PIB per capita nos anos 1991, 2000 e 2010. Enquanto Sul e Sudeste abrigam os municípios mais ricos do país e Centro-Oeste e Norte tem "ilhas de riqueza" cercadas por municípios com níveis intermediários de riqueza, o Nordeste mantém seus níveis estáveis em relação à concentração de pobres. Ou seja, embora o PIB tenha sido levemente alterado, durante todo o período a desigualdade regional permaneceu intacta. (ARRETCHE, 2015)

A delineação constitucional do que vem a ser considerado desenvolvimento, tal como destaca Amartya Sen, deve "ir muito além da acumulação de riqueza e do crescimento do Produto Interno Bruto e de outras variáveis relacionadas à renda" (SEN, 2000). Segundo o conceito de justiça social, desenvolvimento não pode se resumir ao crescimento econômico, já que envolve também a justiça distributiva (que diz que cada cidadão deve receber o que the é devido), as liberdades políticas e os direitos civis, as oportunidades sociais, a transparência na esfera pública e privada e a proteção social. Não faz sentido falar de desenvolvimento sem incluir o acesso irrestrito à educação, à saúde, ao crédito, aos bens públicos, à posse da terra, à titularidade de imóveis e a tudo o que é indispensável a uma vida de boa qualidade em uma sociedade democrática moderna. 
Ademais, como já foi destacado, "os processos de desenvolvimento (econômico e social) e a democracia estão profundamente amalgamados, eis que as liberdades substanciais preenchem de sentido o exercício político" (FACHIN, 2015, p. 159).

O desenvolvimento, em geral, é definido pelos autores como um processo auto-sustentado. Um processo que faz, portanto, as condições de vida se elevarem continuamente ao longo de um dado período. Por conseqüência, a expressão "desenvolvimento autosustentado", na realidade, é tautológica. Se o desenvolvimento não for auto-sustentado, é apenas crescimento, ainda que venha acompanhado de melhorias no tocante ao bem-estar social. (GABARDO, 2009)

Assim, a análise da pobreza e a miséria endêmicas, suportadas por esse modelo de desenvolvimento desconexo das peculiaridades regionais, e gerada em muito pela baixíssima oferta de serviços públicos não pode ser lida através as lentes do viés puramente econômica, em concepções que se apoiam unicamente nos postulados da liberdade. Isso porque, sobretudo "se tomada esta última em uma acepção restritiva, poderia coincidir com a proposta de uma atuação meramente subsidiária de Estado" (HACHEM, 2013).

Note-se que, consoante com a doutrina de Emerson Gabardo, o reconhecimento da relação entre desenvolvimento e subsdiariedade é equivocada. A ordem econômica trazida na Constituição de 1988 não consagrou a subsidiariedade como princípio sequer implicitamente. "O processo de desenvolvimento previsto é de caráter centralizado e estabelece competências próprias para o Estado e para cada um dos entes, além da regulamentação específica que é direcionada à iniciativa privada" (GABARDO, 2009).

Sendo assim, a partir do momento em que Constituição Federal estabelece um modelo de Estado, dispõe objetivos a serem perseguidos por esse modelo, e precisa competências comuns a serem realizadas simultaneamente pelos entes federados (não concebendo qualquer relação de prioridade entre eles), ao contrário de ser retórica, muito claramente determina direções vinculantes e interventivas para o Estado. O constitucionalismo igualitário e a dogmática constitucional emancipatória, portanto, não podem perder isso de vista (CLÈVE, 2012, p. 40).

A análise dos dados trazidos pelos Censos Demográficos do período de 1970 a 2010 confirmam os estudos de economia regional que afirmam que as regiões brasileiras "tornaram-se proporcionalmente mais desiguais entre si e mais homogêneas internamente" (ARRETCHE, 2015, p. 199).

Em períodos de rápido crescimento econômico, a desigualdade de renda per capita entre as regiões tende a se acentuar, em favor do Sudeste. Há "clubes de convergência": o Distrito Federal e o estado de São Paulo lideram o grupo de renda mais alta (concentrado no Sudeste), ao passo que os estados do Nordeste foram o clube de baixa renda. Entre os municípios também há "clubes de convergência" que têm caráter regional, isto é, aqueles de baixa renda estão localizados nas regiões Norte e Nordeste, enquanto os de renda mais elevada concentram-se nas regiões Sudeste, Sul e Centro-Oeste. (ARRETCHE, 2015, p. 199) 
Dessa forma, os indicadores que até aqui foram apresentados demonstram a necessidade de políticas públicas desenhadas especificamente para certas regiões, visto que a concentração da precariedade em certos territórios e das disparidades são reveladas de forma bastante objetiva.

Ademais, tal avaliação demonstra também que a atualidade do debate que se originou na economia política brasileira sobre os chamados espaços de subdesenvolvimento. Os atores sociais tradicionalmente afastados de sua função social - como decorrencia do estruturalismo - não têm conseguido se apropriar devidamente dos frutos do crescimento econômico e promover modificações estruturais na sociedade brasileira, barrando, inclusive, o exercício da cidadania.

\begin{abstract}
Não há verdadeira cidadania sem a garantia de um substrato socioeconômico mínimo, porque desprovidos deste as liberdades civis e políticas ganham contornos meramente formais. Do mesmo modo, os direitos sociais, econômicos e culturais, sem a plena vivência pública, esvaziam-se de sentido porque exauridos do potencial emancipatório que esses direitos trazem consigo. (FACHIN, 2015, p. 159)
\end{abstract}

Nesse sentido, ter em conta a centralidade do elemento subjetivo é essencial à leitura constitucional do desenvolvimento e, especialmente, do desenvolvimento regional. As discussões da regionalização colocam o cidadão como protagonista central do processo de desenvolvimento "não apenas como destinatários dos programas de desenvolvimento econômico e social estatais, mas com voz ativa para seu destino mudar" (FACHIN, 2015, p. 193), tal como se defende na literatura internacionalista, no contexto do humanrights approach.

\title{
A NECESSÁRIA ARTICULAÇÃO FEDERAL PARA ERRADICAÇ̃̃O DA MISÉRIA
}

Com mais de 500 anos de história, e estruturado sob a forma republicana há mais de 100, o Estado brasileiro nunca conseguiu implementar integralmente o modelo de bem-estar social. Isso se dá, em grande medida, pelos fatos da Administração Pública, na maioria das vezes, não seguir as orientações impostas pela Constituição Federal no tocante aos direitos fundamentais e não colocar em prática políticas públicas que assegurem esses direitos, especialmente os direitos fundamentais sociais, de maneira espontânea, igualitária e eficiente. Dessa maneira, a questão da implementação de direitos fundamentais sociais no Brasil, mais do que um problema de gestão, é um problema eminentemente político (KRELL, 2009, p. 635).

A estruturação do modelo federativo brasileiro passou por diversos redesenhos e adequações ao longo das Constituições de 1934, 1937, 1946, 1967 e 1969. Entretanto, a doutrina é consoante em apontar o federalismo brasileiro do período como meramente nominal. Em primeiro lugar, aponta-se a manutenção de desigualdades gigantescas entre as unidades federadas, fato que por si só demonstra a centralização do poder e o pequeno grau de federalização da nação. Além disso, esse sistema acabou por ser gerado dentro de um panorama em que os Estados economicamente mais fortes dominavam a República através de jogos de alianças no seio da governança da União (BERCOVICI, 2001, p. 45). 
Por esses motivos que a promulgação da Constituição Federal de 1988 representou um passo decisivo na remodelagem da organização estatal brasileira. Os indiscutíveis avanços vão além do reconhecimento da Carta Constitucional como documento político-normativo dotado de supremacia, recognição outrora tão apequenada. Isso porque, além dos debates clássicos inseridos nas macrotendências federalistas acerca da repartição de competências entre os diversos níveis de governo, a Constituição de 1988 exigiu o aperfeiçoamento das estruturas federais, sobretudo no tocante às colaborações intergovenamentais e tendo como um dos objetivos fundamentais da República a erradicação da pobreza e o desenvolvimento regional (BERCOVICl, 2008). Assim, se a mitigação dos ditames das Constituições anteriores em matéria de federalismo pode, em maior ou menor medida, sertransigido, com a promulgação do texto de 1988 tal realidade é inaceitável. A Constituição, que ordena e conforma a ordem social e política, a despeito das tensões permanentes entre a realidade e a norma (BARROSO, 2009, p. 80), não pode ter seu texto suplantado por contingências.

Dessa nova roupagem constitucional ao modelo de Estado brasileiro não se é possível a extração de um sistema imediatamente estável institucionalmente. Pelas raízes fortemente oligárquicas e em decorrência de um processo político ainda imaturo no Brasil (JUSTEN FILHO, 2005), a leitura do princípio federativo ainda gera dúvidas e implica em um modelo federativo aberto às mais diversas interpretações. Da ausência de consenso sobre as delimitações, imposições e consequências do federalismo nacional, o princípio fundamental estabelecido no primeiro artigo da Carta Constitucional de 1988 acaba sendo identificado, talvez, como um dos princípios mais frágeis da ordem política brasileira. Isso porque, a realidade não corresponde às significações constitucionais e tem por consequência a impressão de que o princípio, estruturante e fundamental ao Estado brasileiro, assemelhe-se à retórica constitucional.

Tal estabilidade institucional só poderá ser alcançada a partir do momento em que o Brasil atingir estabilidade democrática, com todas as implicações que daí decorrem. E a questão democrática não é, e não pode ser, reduzida apenas à esfera estritamente político-institucional. É necessário que o país vá além e alcance os reais pressupostos da democracia. Tais conjunções, por óbvio, não são atingidas apenas pelo desenvolvimento econômico. Sem que seja assegurada à população condições mínimas para sua emancipação, para seu progresso autônomo - por meio do qual se é garantida, inclusive, a dignidade da pessoa humana -, não há de se falar em um modelo democrático sólido e plenamente implementado.

A despeito do amadurecimento das instituições, no momento em que a Constituição Federal estabelece um modelo de Estado, e dispõe objetivos a serem perseguidos por esse modelo, ao contrário de ser retórica, muito claramente determina direções vinculantes para o Estado e para a sociedade. Tal percepção tem claros impactos sobre as noções que venham a ser adotadas acerca do federalismo, já que é da sua adequada compreensão de que dependem, diretamente, a implementação e a execução de políticas públicas essenciais à proteção dos direitos fundamentais sociais, assecuratórias do desenvolvimento nacional e tendo como primeiro passo a erradicação da miséria extrema. 
As discussões da doutrina jurídica brasileira sobre o tema giram em torno do caráter fiscal, das competências de arrecadação de cada ente e das necessárias transferências tributárias entre eles. Tais, apontam a falência completa do sistema federal pelas baixas condições arrecadatórias das unidades subnacionais e pela opção constituinte por um "federalismo assimétrico". Para Nalini, "é a esperança ou a utopia a funcionar como alento, num Brasil que não fornece motivos para encontrar consistência no ufanismo oficial. Sem isso, resignemo-nos a participar dos momentos derradeiros ou mesmo do velório do ideal federalista. Para alguns, ele agoniza; para outros, já expirou" (NALINI, 2013, p. 344). Porém, o federalismo brasileiro não pode ser dado por morto e enquanto vigente tal ordem constitucional não o poderá ser. Dessa maneira, há urgência no debate do tema como um todo estruturante do Estado e orientador das competências da Administração Pública, não apenas sobre suas especificidades fiscais.

O art. 23, parágrafo único, da Constituição Federal, com ínfimas mudanças em relação à sua redação original, determina que "Leis complementares fixarão normas para a cooperação entre a União e os Estados, o Distrito Federal e os Municípios, tendo em vista o equilíbrio do desenvolvimento e do bem-estar em âmbito nacional". Daí, são de possível extração dois aspectos impactantes e determinantes à identificação do conteúdo do pacto federativo brasileiro.

O primeiro deles é a cooperação entre as unidades federadas. Expressão que, amplamente debatida na orientação federalista de diversos Estados, traz consigo a imposição de atuação conjunta dos entes federativos para a consecução de objetivos comuns. Vale dizer, é a percepção de que as unidades federadas são co-titulares de interesses idênticos. Dessa forma, o federalismo cooperativo impõe a associação antes da rivalidade "e importa, sobretudo entender que os arranjos cooperativos buscam legitimidade numa concepção profundamente democrática de Estado" (SILVEIRA, 2002, p. 8).

Os Estados Unidos foram os primeiros a utilizarem o termo cooperativefederalism $^{8}$, especificamente para apontá-lo como modelo rigorosamente oposto ao então estabelecido (dual federalism), quando da implementação da política do New Deal. A partir daí, diversos países adotaram essa expressão de forma oficial, como é o caso, a título exemplificativo, da Alemanha, da Suíça e da Áustria.

Porém, cada Estado Federal apresenta características próprias que Ihes distingue de todas as demais configurações políticas, embora conservem em suas estruturas princípios regentes comuns. Isso porque, não é excessivo falar, toda execução objetiva de um modelo de Estado surge das relações humanas, de grupos específicos que compartilham valores comuns e interagem culturalmente, e que despontam de processos históricos autônomos (JUSTEN FILHO, 2005). Tal fato, por si só, gera enormes dificuldades de estabelecimento de comparação entre essas estruturas políticas, mesmo que essas adotem a priori um modelo pré-estabelecido, como é o caso do federalismo de cooperação. Sendo assim, a partir da importação de algumas frustrações de tais sistemas, a doutrina brasileira passou a nortear críticas contrárias à implementação das estruturas de colaboração intergovernamental no Brasil sob as lentes de experiências políticas, históricas e socioeconômicas bastante distintas das experiências nacionais

\footnotetext{
Págाna 1405 Atualmente a expressão deixou de ser utilizada pelos autores americanos, sendo substituída pela expressão intergovernmentalrelations.
} 
(KRELL, 2009, p. 635). Entretanto, a Constituição Federal não dá sugestões, e como já dito, ela ajusta toda a estruturação de política e jurídica do Estado. Logo, quando estabelece o princípio da coordenação, gera um dever aos entes federados no que toca sua execução de maneira ótima, não havendo justificativas minimamente sustentáveis para seu afastamento.

O segundo aspecto refere-se ao objetivo supracitado da Federação: o desenvolvimento e o bem-estar como objetivo da cooperação entre as unidades federadas. Desdobramento intimamente ligado com os direitos fundamentais.

A Constituição Federal de 1988 endereçou à Administração diversos deveres para a concretização dos direitos fundamentais. Deveres esses não só de caráter negativo, mastambém de caráter prestacional. Isso porque, antes de 1988 havia um cenário em que se afirmava que esses direitos eram normas programáticas que deveriam ser executados gradativamente e que dependiam de regulação legislativa e administrativa. Um cenário favorável à desconsideração de tais direitos e sua implementação relegada às oscilações momentâneas das agendas políticas.

Com a promulgação da Constituição de 1988, que estabeleceu que os direitos previstos em seu Título II gozavam de aplicabilidade imediata, passou-se a aceitar que, mesmo que esses direitos não tenham seu conteúdo determinado, regulamentado ou especificado pelo legislador, eles podem autorizar a concessão de medidas judiciais para a tutela desses direitos. Fazendo, portanto, com que as omissões da Administração Pública e do Poder Legislativo recebessem contrapeso pelo Poder Judiciário para garantir a efetividade da Constituição.

Junto disso, no início do século XXI, através de uma doutrina inserida em um novo paradigma, o Constitucionalismo Igualitário, a preocupação com a efetividade dos ditames constitucionais tomou como foco a execução de políticas públicas que não só garantissem tais direitos, mas os garantissem de forma igualitária. Isso porque, a mera possibilidade de se acionar o judiciário para que se assegurem tais direitos, não afiança seu acesso a todos os cidadãos. Dessa forma, todos os entes da federação são co-responsáveis por implementar de forma espontânea e igualitária os direitos sociais para que se assegure o desenvolvimento e o bem-estar.

Ocorre que, na opção de se estruturar o Estado brasileiro através de uma federação fortemente assimétrica, "não temos sido capazes de produzir entidades federativas emancipadas, maduras e capazes de liderar e manejar, em seu espaço próprio, políticas públicas imprescindíveis à sociedade" (TAVARES, 2013, p. 240).

Portanto, torna-se imperiosa a superação de formulações clássicas acerca do(s) federalismo(s). A atual leitura da federação brasileira tem Ihe transformado num federalismo de integração, com uma descentralização constitucional aparente, mas que esconde tendências unitárias na medida em que impõe ampla dependência por parte das unidades federadas à União.

Verifica-se, porém, que tal interpretação do princípio do federalismo desconsidera que a Carta de 1988, situada na vanguarda, edificou o federalismo de forma expressa sobre os alicerces do Estado Social (TAVARES, 2013, p. 245). 
Administração condições para que efetive os direitos sociais em sua integralidade (HACHEM, 2014, p. 6), impõe, precipuamente, uma releitura do modelo de Estado em que nos inserimos.

Tal modelo organizacional não pode ser imune à preocupação com os direitos fundamentais, "especialmente aqueles que demandam do Estado uma atuação positiva que envolve custos operacionais, econômicos e custos de arranjo político" (TAVARES, 2013, p. 245). E é justamente por isso que a introdução de dissabores com mecanismos de cooperação das mais várias espécies não pode ser admitida para que se rechace a própria imposição constitucional de cooperação intergovernamental.

Também como forma de abandonar preconceitos ao federalismo de cooperação, entende-se necessário o apontamento de uma leitura federativa alinhada à noção de federalismo social, ou seja, "o reconhecimento de que a estrutura federativa demanda um desenho próprio de responsabilidades na consecução de direitos fundamentais, capaz de comprometer as entidades federativas no compromisso constitucional com a realização de direitos prestacionais de cunho social, econômico e cultural." (TAVARES, 2013).

Logo, a orientação da agenda das unidades federadas deve, em primeiro lugar, estar atenta às necessidades básicas da sociedade. Adotar o federalismo social como filosofia orientadora da relação entre as unidades federadas significa dirigir a gestão pública diretamente ao atendimento das necessidades da pessoa humana, seja individualmente, seja enquanto membros de uma coletividade, delimitada ou não. Para isso, é necessário o desenvolvimento, em toda a Administração Pública, de mecanismos que possibilitem implementação de políticas que assegurem a igualdade entre os cidadãos, não perdendo de vista as peculiaridades regionais e a autonomia dos entes. Isso porque, quando o Estado planifica determinada política pública, mais do que fomentar ou impulsionar o crescimento da produtividade ou incrementar a renda, ele tem o dever de harmonizar o desenvolvimento regional. Imposição que só será cumprida através do diálogo e colaboração entre os diversos níveis de governo.

A Constituição Federal de 1988, extremamente analítica, por meio de seus fundamentos e objetivos, estabelecidos nos artigos 10 e 3 , através do reconhecimento da fundamentalidade dos direitos sociais previstos no artigo 60 , através do estabelecimento, no art. 170 , da redução das desigualdades regionais e sociais como princípio norteador da ordem econômica e social, e ao dispor em seu art. 193 que "a ordem social tem como base o primado do trabalho, e como objetivo o bem-estar e a justiça sociais", oferece todos os subsídios normativos para que a Administração Pública desenvolva programas que objetivem a erradicação da pobreza, sobretudo a erradicação da extrema miséria.

Durante os dois mandatos de Fernando Henrique Cardoso, algumas primeiras medidas foram criadas para coordenar e, mormente, modificar as relações entre os governos subnacionais, observadas as limitações impostas pelas conjunturas políticas e econômicas.

A fortíssima crise fiscal do período, dentro do cenário peculiar da "Era Real”, foi favorecida com o fim da inflação, já que os Estados deixaram de receber créditos advindos do floating que possibilitava elevação e diminuição artificial de suas receitas e despesas. Somando-se a isso, as elevações das taxas de juros afetaram frontalmente os títulos e dívidas dos bancos estaduais que acabaram 
entrando em bancarrota. Por fim, com a adoção de medidas arrecadatórias centralizadoras a crise dos Estados foi ainda mais agravada. "Um balanço geral dos anos FHC mostra que, em parte, ele conseguiu constituir um "momento maquiaveliano" no jogo federativo, tendo a virtù para criar uma nova ordem. Em outros aspectos, todavia, isso não foi feito, permanecendo o legado do federalismo desenvolvido durante a redemocratização e ainda com algumas influências da trajetória histórica das relações intergovernamentais do país" (ABRUCIO, 2005, p. 51-52).

Daí, uma das maiores dificuldades de coordenação entre os entes federativos se deu em razão do país ter adotado uma postura descentralizadora antes mesmo da estabilização da economia, sobretudo no que diz respeito às transferências financeiras. Dessa forma, somente diante da crise é que se foi possível a repactuação positiva de colaboração financeira entre as unidades federadas e que a pauta da (des)centratilização de determinadas políticas públicas fosse colocada em discussão.

Entretanto, mesmo com todas as dificuldades, importantes programas foram iniciados em seus dois mandatos. Ressalta-se a instituição de planos de distribuição de renda como o Programa de Erradicação do Trabalho Infantil (Portaria-MPAS no 2917/2000), o Programa Renda Mínima (Lei no 10.219/2001), o Programa Bolsa-Escola (Lei no 10.219/2001), e o e Vale-Gás (Medida Provisória no18/2001), bem como a regulamentação do Programa Vale-Alimentação (Lei no 6.321/1976). O estabelecimento de tais projetos nacionais exigiu esforços conjuntos das unidades regionais, uma vez que a suas execuções contaram com mecanismos de operacionalizações locais com garantia de transferências de verbas padronizadas por parte da União. Além desses programas, Emendas à Constituição também criaram novas condições ao tratamento federalista brasileiro. É o caso da aprovação do Fundef, a aprovação da chamada "PEC da saúde" e da criação do Fundo de Combate e Erradicação da Pobreza.

Diante da impossibilidade de mapeamento de todos os desdobramentos das políticas públicas implementadas sobre o comando de Fernando Henrique Cardoso, é importante apenas ressaltar que, embora correspondam avanços em relação aos mecanismos federativos, muitas dessas políticas foram pulverizadas em grande parte dos Estados e Municípios. Os fóruns intergovenamentais para discussão de resultados e perspectivas de tais programas quase que inexistiram. Obviamente que questões de comprometimento estadualista e municipalista estão além da alçada da União, "mas o fato cabal é que o governo FHC não teve um projeto claro de desenvolvimento regional. Ao contrário, desmantelou órgãos incumbidos de tal tarefa, fragmentou políticas para esta área e não propôs uma alternativa ao modo anterior" (ABRUCIO, 2005, p. 51-52).

Dessa forma, sobretudo a partir de 2003, com o governo Lula, o Governo Federal marcou presença constante, atuando na economia e nas relações sociais. Os diversos programas executados no período anterior foram unificados no Programa conhecido como "Bolsa Família», que passou a ser gerido pelo Ministério do Desenvolvimento Social e Combate à Fome. Os objetivos do Bolsa Família, dispostos no art. 4o do Decreto Presidencial no 5.209/2004, dentre outros, compreendem o combate à fome e a promoção da segurança alimentar e nutricional; o estimulo da emancipação sustentada das famílias que vivem em situação de pobreza e extrema pobreza; o combate à pobreza e; a promoção da "intersetorialidade, a complementaridade e a sinergia das ações sociais do Poder 
Público". Os resultados dessa política são significativos. O Brasil, no período de 2001 a 2011, conseguiu reduzir as linhas de pobreza e extrema pobreza em mais de $55 \%$, fato que não ocorria, de maneira contínua e de tamanha monta, desde meados da década de 1960'. O Índice Geni em 2001 chegou a 0,61, já em 2011 alcançou os 0,527. Diante desses avanços, Marcelo Neri, presidente do Instituto de Pesquisa e Economia Aplicada à época, chegou a afirmar, inclusive, que o país havia cumprido a meta do milênio.

Seguindo os encaminhamentos do governo anterior para políticas de redistribuição de renda, o governo de Dilma Rousseff estabeleceu em 2011 o Plano «Brasil sem Miséria» (Decreto Presidencial n. 7.492/2011) objetivando superar a extrema pobreza até o ano de 2014. Levando em consideração as diversas formas de manifestação da pobreza, o Plano estabeleceu uma atuação em três frentes: a garantia de renda, como mecanismo imediato de superação dos índices, a garantia de acesso pela população aos serviços públicos e a inclusão produtiva, visando a capacitação e inserção dessa parcela da população no mercado de trabalho. Os resultados oficiais do programa foram vultosos especialmente no que se refere à população mais jovem: a situação de extrema pobreza na faixa dos 0 a 15, no período de 2003 a 2014, foi abandonada por $89 \%$ da população.

Portanto, é perceptível que nos três últimos governos, a Administração Pública Federal caminhou para uma gestão pública inclusiva, abandonando as tradicionais correntes legalistas, através uma crescente constitucionalização do Direito Administrativo e com inserção gradativa no paradigma do Estado Social ${ }^{10}$.

O ambicioso desafio a que se propôs o Plano Brasil sem Miséria não teria como subsistir sem que houvessem apoio de governos municipais e estaduais. Isso porque, para que o programa alcançasse os seus fins, as peculiaridades regionais e locais deveriam ser observadas. Nesse contexto, então, ao momento em que a União traçava estratégias amplas e definia mecanismos gerais e de baixa complexidade, Estados e Municípios encarregavam-se de executar tais políticas e propor novos mecanismos que, alinhados às diretrizes do Plano, se adaptassem às peculiaridades das Regiões.

Pela primeira vez, desde a promulgação da Constituição Federal de 1988, um programa conseguiu mobilizar esforços dos três níveis federativos, para consecução de um objetivo comum. E esse é o grande legado do programa ao arquétipo federativo brasileiro. $O$ Plano Brasil sem Miséria é um marco do que alguns autores chamaram de "novo Federalismo Social" (NERI, 2012).

9 Tendo em vista que o objeto do presente estudo não é direcionado aos resultados estatísticos dos programas de governo, mas sim seus avanços em relação às práticas de promoção de políticas de desenvolvimento regional e, nesse tópico, especialmente as experiências de coordenação, utilizam-se os dados oficiais para análise das políticas públicas de superação da pobreza, nos governos Lula e Dilma, formulados pelo Instituto Brasileiro de Geografia e Estatística.

10 Os programas constantes do Plano Brasil sem Miséria foram amplamente apoiados, tanto pelos partidos situacionistas como os partidos de oposição. Como objeto exemplificativo, cite-se as emendas propostas pelo Democratas (DEM) à Medida Provisória n ${ }^{\circ}$ 535/2011, que instituiu o Programa de Apoio à Conservação Ambiental e o Programa de Fomento às Atividades Produtivas Rurais (convertida na Lei n ${ }^{\circ} 12.512$, de 14 de outubro de 2011). Também, durante a campanha presidencial de 2014, os candidatos Aécio Neves (PSDB), Marina Silva (PSB), Luciana Genro (PSOL) e Eduardo Jorge (PV), propunham a ampliação dos programas. Aécio Neves, então Senador da República, em 2013 chegou a afirmar que Pásériazmecessária a incorporação do Programa Bolsa Família à Lei Orgânica de Assistência Social (Lei nº 8.742, de 07 de dezembro de 1993), argumentando que, ao ser incorporado em legislação mais robusta como a LOAS, o programa ficaria "assegurado como política de Estado, e não mais como política de governo ou de partido". 
A articulação federativa se deu por meio de pactuações entre o Governo Federal, através de suas pastas, Governadores, e com intervenções de presidentes de associações municipalistas. Ainda, para que o programa fosse viabilizado, contou-se inclusive com a colaboração de organizações da sociedade civil, como pode ser observado na tabela abaixo, que embora não exclua outras ações e parceiros, é de grande valor representativo.

TABELA I - Parceiros do Brasil sem Miséria por Macroprocessos (BRASIL, 2014, p. 135136)

\begin{tabular}{|c|c|c|}
\hline Macroprocessos & Principais Macroações & Parceiros \\
\hline \multirow[t]{9}{*}{$\begin{array}{l}\text { Inclusão Produtiva } \\
\text { (urbana e rural) }\end{array}$} & $\begin{array}{l}\text { Qualificação profissional } \\
\text { (Pronatec Brasil sem } \\
\text { Miséria) }\end{array}$ & $\begin{array}{l}\text { MEC, MDS, estados, municípios e unidades } \\
\text { ofertantes (Sistema S, Institutos Federais e } \\
\text { Redes Estaduais de Ensino Técnico) }\end{array}$ \\
\hline & $\begin{array}{l}\text { Microempreendedor } \\
\text { individual }\end{array}$ & Sebrae, estados e municípios \\
\hline & $\begin{array}{l}\text { Economia popular e } \\
\text { solidária }\end{array}$ & MTE, estados e municípios \\
\hline & $\begin{array}{l}\text { Intermediação de mão de } \\
\text { obra }\end{array}$ & TEM, MDS e municípios \\
\hline & $\begin{array}{l}\text { Microcrédito Produtivo } \\
\text { Orientado (Crescer) }\end{array}$ & $\begin{array}{l}\text { Banco do Nordeste do Brasil, Caixa } \\
\text { Econômica Federal, Banco da Amazônia, MF, } \\
\text { MTE, MDS, estados e municípios }\end{array}$ \\
\hline & Programa Água para Todos & $\begin{array}{l}\text { MI, MDS, Funasa, MMA, Fundação Banco do } \\
\text { Brasil, estados e municípios }\end{array}$ \\
\hline & Programa Luz para Todos & MME, MDS, estados e municípios \\
\hline & Programa Bolsa Verde & $\begin{array}{l}\text { MMA, ICMBio, Incra, Secretaria de } \\
\text { Patrimônio da União (MP), MDS, estados e } \\
\text { municípios }\end{array}$ \\
\hline & $\begin{array}{l}\text { Inclusão no campo: } \\
\text { Assistência Técnica e } \\
\text { Extensão Rural (ATER), } \\
\text { sementes e fomento }\end{array}$ & $\begin{array}{l}\text { MDS, MDA, Incra, ICMBio, Funai, MPA, } \\
\text { SEPPIR, Fundação Cultural Palmares, estados } \\
\text { e municípios }\end{array}$ \\
\hline \multirow[t]{2}{*}{ Garantia de Renda } & Programa Bolsa Família & MDS, estados e municípios \\
\hline & $\begin{array}{l}\text { Benefício da Prestação } \\
\text { Continuada (BPC) }\end{array}$ & MDS, INSS, estados e municípios \\
\hline \multirow{4}{*}{$\begin{array}{l}\text { Acesso a serviços } \\
\text { públicos nas áreas } \\
\text { de saúde, educação } \\
\text { e assistência social }\end{array}$} & $\begin{array}{l}\text { Ação Brasil Carinhoso } \\
\text { Creches }\end{array}$ & MEC, MDS, FNDE, Inep, estados e municípios \\
\hline & Escola em Tempo Integral & MEC, MDS, estados e municípios \\
\hline & Ação Brasil Carinhoso Saúde & MS, estados e munícipios \\
\hline & Assistência Social & MDS, estados e municípios \\
\hline Busca Ativa & Cadastro Único & $\begin{array}{l}\text { MDS, organizações representativas de } \\
\text { populações tradicionais e específicas, estados } \\
\text { e municípios }\end{array}$ \\
\hline
\end{tabular}


Dessa forma, o Ministério do Desenvolvimento Social e Combate à Fome é o órgão incumbido de coordenar a atuação intersetorial para a execução do Plano. A principal inovação está presente no fato de que "ao contrário de experiências anteriores com grandes iniciativas de natureza intersetorial, a coordenação do Brasil sem Miséria não foi entregue a um órgão central da Administração Federal, mas a um ministério setorial" (BRASIL, 2014, p. 147), até porque, por não ter natureza de órgão central, o processo decisório é um tanto quanto mais simples, tendo como uma das consequências, a facilitação do monitoramento de desempenho do programa. Para funcionamento do Plano, a pasta conta com três níveis de governança: o Comitê Gestor Nacional, o Comitê Executivo e o Grupo Interministerial de Acompanhamento (GIA). Além disso, para coordenação da estratégia de combate à extrema pobreza, criou-se a Secretaria Extraordinária para Superação da Extrema Pobreza (Sesep).

Entretanto, embora serem os esforços do Governo Federal, em alguma medida, louváveis e aparentemente bem intencionados, são ainda um passo muito curto na real percepção das imposições constitucionais no que tocante à proteção e prestação de direitos fundamentais sociais e no modo de relacionamento federativo. É o que se passa a analisar.

\section{ANOS DE CONSTITUIÇÃO, 28 ANOS SEM A IMPLEMENTAÇÃO INTEGRAL DE DIREITOS SOCIAIS BÁSICOS}

Embora da dignidade da pessoa humana decorram direitos fundamentais, inclusive não enumerados na Constituição, trata-se de um conceito jurídico indeterminado, um conceito vago, de contornos imprecisos. Dessa forma, diversas são as tentativas de se encontrar critérios que o delimitem tal princípio. Adotam-se os critérios de Luís Roberto Barroso $(2012)^{11}$ e de Ana Paula de Barcellos (BARCELLOS, 2011) ${ }^{12}$ para identificação do mínimo existencial.

Para os autores, o mínimo existencial compõe a zona sindicável do princípio da dignidade da pessoa humana. Assim, a prestação de políticas públicas que assegurem o núcleo material da dignidade da pessoa humana não está à mercê do juízo de oportunidade e conveniência do administrador (ZANETI JR., 2010), até porque, mais do que uma atividade sublegal, infralegal, a atividade administrativa não poderá deixar de considerar as necessárias relações de subsunção, não só em relação à lei, mas, sobretudo, à Constituição (MELLO, 1993). Nesse sentido, o Plano Brasil sem Miséria, traz em sua estruturação avanços e objeções.

Em primeiro lugar, em relação ao direito à educação básica, em pouco contribui. Instituiu-se na área educacional o Plano o Programa Nacional de Acesso ao Ensino Técnico e Emprego (Pronatec). Entretanto, ao mesmo tempo em que é essencial que o Estado conceda oportunidades educacionais e de formação profissional, em relação aos postulados constitucionais, o Estado segrega aqueles que há muito foram segregados. Isso porque, em situações de miséria extrema, milhares de cidadãos brasileiros ainda vivem em municípios, em

11 Para o autor, o mínimo existencial seria identificado como desdobramento do princípio da dignidade da pessoa humana como autonomia. Isso porque, não há como um indivíduo ser autônomo sem que lhe seja garantido um mínimo que Págaranta sua existência. Logo, o mínimo existencial é o substrato material para o desenvolvimento autônomo do ser humano. 12 Admite-se que o mínimo existencial se compõe pelo direito à educação básica, à saúde básica, ao auxílio aos desamparados e ao acesso à justiça. 
comunidades, que sequer Ihes garantem acesso à educação básica. O Brasil ainda abriga - e quando abriga - diversas escolas que funcionam em situações extremamente precárias, com ensino multisseriado. A implementação das Escolas em Tempo Integral traz resultados ainda pouco vultosos, não sendo o principal foco dos entes federados e do próprio Plano Brasil sem Miséria.

Se o objetivo do Plano é a erradicação da pobreza, tendo em vista o plano educacional da questão, a prioridade governamental deveria ser a educação básica, podendo, por óbvio ser somada a programas que visem à profissionalização. Nesse sentido, mais uma vez se faz de suma importância a coordenação das políticas públicas com atenção especial às áreas em que, embora pertencentes ao território, o Estado brasileiro ainda não chegou. Para isso, nesse aspecto, é essencial a atuação efetiva da Associação Brasileira de Municípios em conjunto com o Ministério da Educação, para que identifique as vulnerabilidades da educação fundamental e estabeleça políticas conjuntas, sejam regionais, sejam federais para que, num primeiro momento, assegure-se o mínimo educacional e se avance um pouco mais no desafio de se erradicar a miséria.

O direito à saúde básica engloba o atendimento materno-infantil, as ações de medicina preventiva, as ações de prevenção epidemiológica e a prestação de serviços de saneamento (BARCELLOS, 2011, p. 313). Os projetos englobados pelo Plano, com destaque ao Programa Água para Todose ao Programa Mais Médicos, são sem sombra de dúvidas avanços. O primeiro programa teve como um de seus focos a entrega de cisternas para diversas famílias, diante da percepção de grande seca que alcança, sobretudo, a região norte e nordeste do país, assegurando assim o acesso à agua para consumo humano. Em relação ao Mais Médicos, o programa visou a melhoria do Sistema Único de Saúde na medida em que adotou como principal objetivo o preenchimento das falhas com recursos humanos de áreas em que há escassez e ausência de profissionais da saúde, sobretudo municípios com alta vulnerabilidade social e Distritos Sanitários Especiais Indígenas (DSEI). Entretanto ainda faltam mecanismos claros e concretos que assegurem o saneamento básico integralmente.

Sobre esse último aspecto, ainda há muito a ser feito para a apreensão da chamada "função social da cidade" e à concretização do "direito de morar dignamente". Embora os estudos estatísticos acerca do acesso ao saneamento básico tomem por base os domicílios permanentemente urbanos, é possível afirmar, de acordo com o IBGE que no Brasil aproximadamente um quinto da população não tem acesso ao sistema de saneamento básico, que engloba tratamento de água e esgoto, coleta de lixo adequada, e tantos outros aspectos. Por isso, faz-se necessário aqui, precipuamente, a discussão do planejamento das áreas e agrupamentos urbanos e rurais.

É preciso destacar que o tratamento constitucional dado à política urbana segue a coerência do pacto político positivado, onde a dignidade da pessoa humana é seu maior fundamento. A leitura atenta leva à compreensão [...] da finalidade de natureza social dos dispositivos 182 e 183 do texto normativo, organizando a propriedade urbana e compatibilizando o conceito de propriedade às demandas sociais. (CASIMIRO, 2008)

Dessa maneira, embora seja o município o ente responsável para tanto, diante da situação extremamente precária pela qual passam alguns municípios, 
seja pela má gestão, seja pela ausência de condições financeiras, clara é a necessidade de instrumentos de cooperação nesse sentido. A cooperação aqui, não se dará somente através de transferências voluntárias, mas também através de convênios e contratos de cooperação.

Por fim, um dos aspectos que mais merecem destaque no Plano Brasil sem Miséria: os programas de garantia de renda. A despeito de todas as discussões acerca do adequado valor de repasse direto aos cidadãos para que se assegurem condições mínimas, para Ana Paula de Barcellos, "o vital é que os desamparados tenham onde obter socorro, seja através de prestação direta pelo Estado, de conveniados do Poder Público, de vales, ou de qualquer outra forma que a inteligência política possa imaginar" (BARCELLOS, 2011). Tal atuação governamental, iniciada na década de 90 e aprimorada e desenvolvida até hoje, insere-se em uma mudança do Estado Indenização para o Estado de Inserção (ROSANVALLON, 1998).

A coordenação aqui também se fez fundamental para possibilitar o Cadastramento Único no Programa. Entretanto, ainda existe a necessidade de aperfeiçoamento das técnicas de busca ativa das milhares de pessoas, que se enquadram no perfil de assistência do Governo, além de garantir-lhes todo aparato burocrático para sua inserção no Programa. Dessa forma, em um primeiro momento significa dizer que o Estado deve buscar cidadãos vulneráveis e não ao contrário, e, após, garantir-lhes meios de acesso às documentações necessárias para o cadastramento no Programa. Além dos cidadãos que vivem em condições insalubres em locais extremamente afastados, sem qualquer consciência, inclusive, de seus direitos; têm aqueles que vivem em situação de extrema pobreza, sem qualquer apoio governamental, por não possuírem CPF ou Título de Eleitor, documentos necessários ao cadastramento no Programa.

Dessa forma, são claros os desafios da Administração Pública para garantia do mínimo existencial e dos direitos fundamentais sociais como um todo. Tais desafios tendem a ser superados em grande parte através de um pacto federativo socialmente engajado.

A presente atuação entre os entes federados corresponde a avanços, como já demonstrado. Entretanto, todas as dificuldades apresentadas necessitam de algo mais.

O grande desafio imposto pela opção federativa brasileira é o fornecimento de políticas públicas que, ao mesmo tempo em que não desconsiderem as particularidades locais, garantam o acesso aos direitos fundamentais sociais de maneira igualitária.

O estabelecimento de um Estado Federal fortemente assimétrico é incontestável e extraído da simples leitura da Carta Constitucional de 1988. Embora a assimetria, por si só, não seja disfuncional ao sistema, os graus em que ela se apresenta são de extrema relevância. No Brasil as assimetrias são apresentadas através da realidade fática e do próprio direito.

Em relação às assimetrias impostas pelo ordenamento jurídico, podemos ressaltar a distribuição de competências que prioriza fortemente a União e a distribuição das capacidades arrecadatórias de estados e municípios. Já as assimetrias fáticas são de várias naturezas, podendo ser destacadas as diferenças territoriais, populacionais, de riquezas, naturais. 
Em Federações, é inevitável alguns níveis de interdependência entre os entes que a compõe. Entretanto, o que há no Brasil é uma atuação autoritária do governo central e uma ampla dependência das unidades federadas aos comandos da União. E as características dispares de cada parte do território brasileiro favorecem essas tendências centralizadoras.

Dessa maneira, e para afastar as predisposições centralizadoras, é que se fazem necessárias políticas cooperativas visando afastar ou, melhor, equilibrar as desigualdades regionais, e atribuir faticamente autonomia aos entes federados. Autonomia essa, necessária inclusive para que cumpram suas obrigações constitucionais em relação aos direitos fundamentais.

Há o dever mútuo de socorro entre os componentes da Federação. Entretanto, é preciso que a cooperação esteja bem definida e delimitada para que se assegure igual comprometimento e divisão razoável dos ônus da própria cooperação, sob pena de se caminhar em sentido contrário ao da própria ideia de Federação.

Nesse sentido apresenta-se o maior pecado do Plano Brasil sem Miséria que, embora não Ihe seja um privilégio, é latente ao passo em que o Plano é identificado com um novo federalismo social: os arranjos formais de cooperação federativa são aparentes e perpetua-se a ideia de um federalismo de integração.

$O$ debate cinge-se nas medidas em que "os entes subnacionais deveriam ser fortalecidos e deter maior capacidade de formulação e implementação de políticas públicas, por um lado; ou que o governo central deva lançar mão de mecanismos para promover uniformização e igualdade territorial entre os entes federados conforme sua prioridade em termos de políticas públicas" (PALOTTI, 2014, p. 402).

Logo, para que sejam alcançados os postulados de um federalismo social fazem-se necessárias duas ações: a ampliação da autonomia dos entes subnacionais, e as mudanças de posicionamento da Administração Pública frente suas obrigações referentes aos direitos sociais.

Em alguma medida, o Plano Brasil sem Miséria traz consigo novas diretrizes e um ótimo exemplo para os demais entes da Federação em termos de sistematização de políticas que visem a implementação espontânea desses direitos. Demonstra que ao menos o governo central tem caminhado para o reconhecimento de que a programaticidade da Constituição brasileira estabelece programas mínimos que devem ser implementados por todo e qualquer governo, ou seja, "ações político-administrativas sem a mínima possibilidade de fuga do script constitucional" (BRITTO, 2012, p. 102). Porém as circunstancias demonstram que a Administração Pública, como um todo, ainda não foi capaz de inserir-se e adequar-se plenamente ao modelo constitucional proposto. Isso porque, o Estado ainda não é capaz de assegurar à população sequer o mínimo existencial, embora venha mobilizando esforços para tanto.

Em segundo lugar, o Plano Brasil sem Miséria reduz estados e municípios à condição de órgãos de execução de políticas públicas. A capacidade decisória de tais entes é reduzidíssima. De tal modo, que as dificuldades que se encontram, conforme demonstrado anteriormente, poderiam ser solucionadas, ao menos em maior medida, através de um caminho inverso de formulação de tais políticas. 
Significa dizer que, sobretudo as políticas públicas que visam a diminuição de desigualdades regionais e desenvolvimento, deveriam ser debatidas primeiramente em fóruns regionais e sub-regionais, através de um processo profundamente democrático, para que se identificasse os maiores obstáculos à sua implementação e as mais urgentes necessidades de suas populações, para só então o governo central criar mecanismos genéricos de uniformização e controle de tais políticas.

Os desafios da tomada de decisão conjunta que essa proposta impõe são diversos, entretanto são parte de um processo de aperfeiçoamento institucional da Administração Pública. Além disso, o modelo não está proposto de forma acabada, como dito incialmente, tratando-se, sim, de um modelo em construção que visa a busca da efetivação igualitária dos postulados constitucionais.

Nesse sentido, então, não podemos afirmar que o Plano Brasil sem Miséria configura um novo federalismo social porque nunca conseguimos alcançar o federalismo social. Porém, podemos com certeza afirmar que o Plano é um bom exemplo e sobretudo o início de um desenvolvimento gradativo de uma nova Administração Pública humanista e de um relacionamento entre as unidades federadas que privilegie a proteção de direitos fundamentais ao mesmo tempo em que garante suas autonomias.

\section{COMO ENCARAR A REGIONALIZAÇÃO E DEFINIR POLÍTICAS PÚBLICAS EFICIENTES EM SEU "SENTIDO HUMANO": EM BUSCA DE NOVOS INDICADORES}

O conceito de território passou a ser utilizado com mais frequência na agenda governamental, de maneira que diversas políticas públicas nos anos recentes, nas mais diferentes estruturas e escalas de governo, se reportam a ele para justificar a adoção de um novo programa ou uma nova metodologia de intervenção.

A abordagem territorial, da forma como vem sendo anunciada, almeja designar um novo paradigma para o planejamento de políticas públicas no Brasil, que se distinga dos antigos instrumentos de planejamento adotados por um Estado centralizador e autoritário. No entanto, a apropriação deste conceito, enquanto instrumento operacional para as políticas governamentais, ainda se encontra difuso e carente de uma melhor fundamentação teórica e operacional, de maneira que ele não perca seu significado e torne-se uma mera adjetivação retórica nas peças normativas oficiais.

Toda ação política é territorializada, uma vez que ela se reveste de um corpo normativo a ser compartilhado socialmente e que incide sobre um determinado espaço. As leis que regem o Estado nacional, por exemplo, estabelecem recortes territoriais para a ação do próprio Estado - por meio de suas políticas públicas -, da iniciativa privada e da sociedade que se origina em ações coletivas. Esta repartição também significa estabelecer limites e possibilidades de ação para aqueles que, no território, estão sob influência das normas estabelecidas.

O entendimento de espaço e território baseia-se nas seguintes categorias: sociedade, natureza, modo de produção, formação econômica e social, tempo, totalidade, técnica e divisão do trabalho. O espaço é um elemento histórico e social, pois determina todos os processos constitutivos de um modo de produção - produção, distribuição, consumo e circulação -, ou seja, é o espaço concreto da 
atividade humana. Dessa maneira, o espaço geográfico não é um mero receptor das ações humanas, uma vez que ele possui um valor de uso e um valor de troca, distintos significados e é elemento constituinte do território, pois eles são indissociáveis. Estes valores, que variam segundo o movimento da história e o conjunto dos lugares, caracterizam o espaço geográfico e são determinantes, em grande medida, das disputas em torno de seus usos e domínios. (SANTOS, 2008)

A partir desse debate, pode-se estabelecer uma definição sintética de território como um espaço de construção social e poder instituído - porém não imutável -, caracterizado por recursos físicos específicos - naturais e industriais - e valores - históricos e culturais - que estabelecem elementos de identidade aos sujeitos que nele habitam. Considera-se também que o território é formado tanto por lugares contíguos - relações de vizinhança - como lugares em rede processos sociais que ligam lugares diferentes. Sob este entendimento, o território constitui uma base flexível sobre a qual agem distintas forças endógenas e exógenas, de maneira que ele se encontra continuamente submetido a relações de poder - conflitivas e/ou cooperativas - nos processos históricos de apropriação e dominação do território, bem como pressões por mudanças, que podem implicar expansão ou deslocamento. (SILVA, 2003)

É necessário pensar uma integração das diferentes iniciativas para cada região, uma vez que a implementação do processo de gestão depende de um amplo processo interativo entre planos, projetos e programas nas diferentes instâncias governamentais.

FIGURA 1 (MATTEO, 2003)

Estrutura no processo de formulação e acompanhamento de ações governamentais

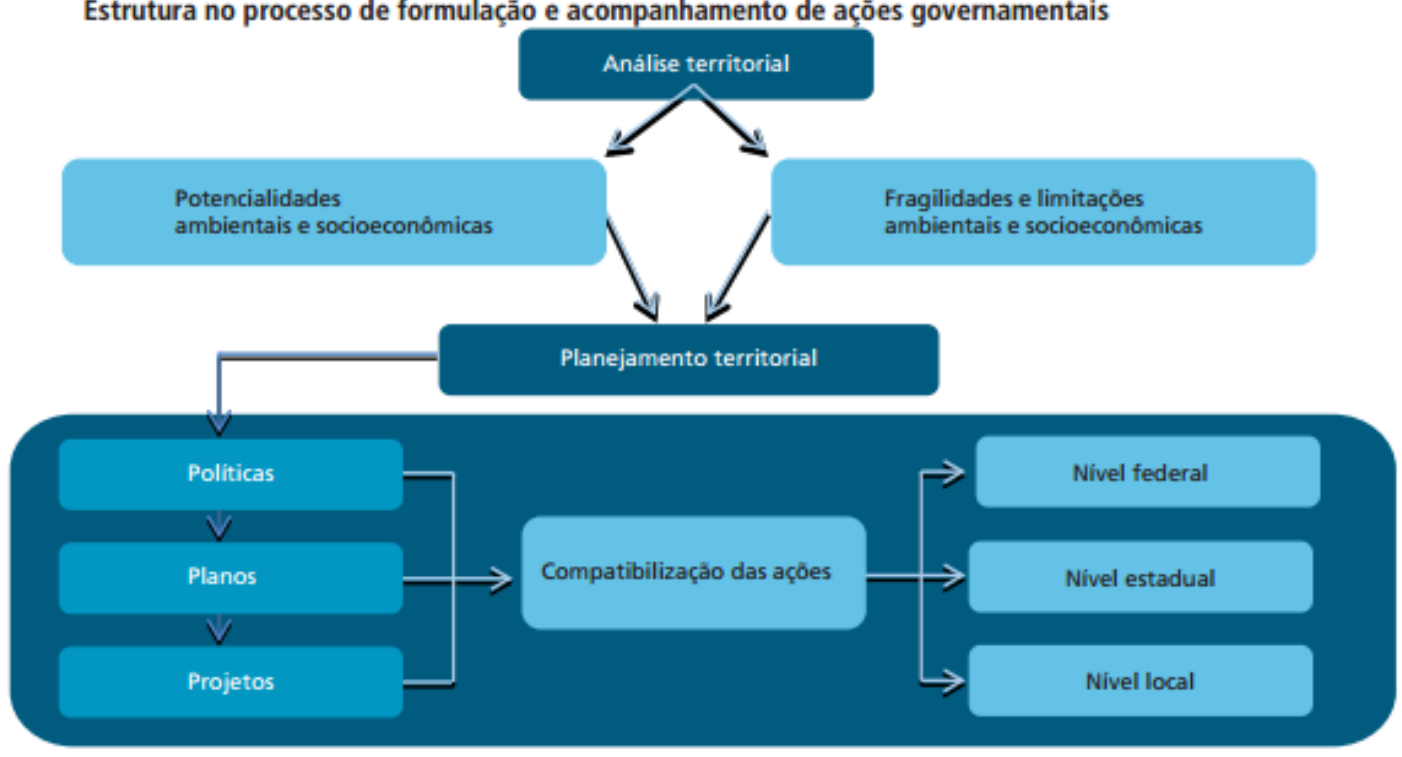

O Decreto no 6.047, de 22 de fevereiro de 2007, instituiu a Política Nacional de Desenvolvimento Regional (PNDR), com objetivo reduzir as desigualdades de nível de vida entre as regiões brasileiras e promover a equidade no acesso a oportunidades de desenvolvimento. Tem como uma das suas principias funções orientar os programas e ações federais no território nacional, atendendo ao disposto no inciso III, do Artigo 3 o da Constituição Federal.

Segundo o Sumário Executivo da PNDR, no Brasil, as desigualdades regionais constituem um fator de entrave ao processo de desenvolvimento. 
No Brasil, as desigualdades regionais constituem um fator de entrave ao processo de desenvolvimento. A unidade da federação com o Produto Interno Bruto per capita (a preços de mercado) mais elevado supera em cerca de 9 vezes o da unidade pior situada neste indicador. Ora, essas diferenças de capacidade de produção refletem-se diretamente sobre as perspectivas de qualidade de vida das populações que residem nos estados mais pobres. As desigualdades possuem, assim, aguda expressão regional no Brasil, diferenciando os cidadãos também com relação ao seu domicílio e local de trabalho.

O Ministério da Integração Nacional (MI) entende que o caminho de redução das desigualdades passa pela valorização da magnífica diversidade regional do país. Isto significa dizer que o problema regional brasileiro encontra uma via de superação na exploração consistente dos potenciais endógenos de desenvolvimento das diversas regiões do país.

De acordo com a Constituição Federal de 1988 (CF/88), a questão regional é assunto de competência direta do Estado. Porém, diferentes autores apontam críticas à base de referência regional brasileira atual, quando, na realidade, existe uma diversidade de padrões territoriais e regionais presentes na definição e na função de cada núcleo de convívio. A região, por exemplo, pode ser entendida como uma "subunidade, um subsistema do sistema nacional", que "não tem existência autônoma" em relação ao espaço nacional, "é um subespaço do espaço nacional total". Ela representa uma referência associada à localização e extensão de um determinado fenômeno, correspondendo a entidades espaciais de escala média, entre o nacional e o local. [...] a divisão administrativa do país em macrorregiões e as divisões dos estados em microrregiões homogêneas são utilizadas como quadros de referência para compreender e apresentar diferentes fenômenos, sejam eles demográficos, sociais, produtivos e geográficos. Além disso, há a constatação das limitações do município em gerir programas governamentais estratégicos, que muitas vezes exigem a ampliação das ações para além de seus limites políticos. (SILVA, 2013)

Assim, o Ministério expressa uma tipologia sub-regional para sua abordagem territorial por meio da Política Nacional de Desenvolvimento Regional. Esta tipologia serve de referência na seleção e priorização das sub-regiões nas quais devem ser aplicados os fundos constitucionais com vistas à diminuição das desigualdades regionais, exclusivamente para o caso de fomento às atividades produtivas. Para isto, utiliza-se uma metodologia baseada nos indicadores microrregionais de renda per capita e na variação do PIB.

Em primeiro lugar, a política parte de uma concepção de Estado diversa da estabelecida na Constituição. Um Estado subsidiário. Ademais, conforme já destacado, a leitura do desenvolvimento a partir de preceitos da justiça social, não poderá basear-se apenas no crescimento econômico, como dispõe a PNDR, já que envolve múltiplas variáveis. Utilizar-se do PIB como indicador da política pública desenvolvimentista, certamente gerará uma abordagem insuficiente e que, inevitavelmente, não comportará a consecução do determinado pela Constituição Federal. 
Afinal, o PIB (e, principalmente, o PIB per capita) capta somente a renda média do país, não capturando aspectos importantes para o bem-estar, como distribuição de renda, incidência de pobreza, preservação do meio-ambiente e qualidade de vida de forma mais abrangente. Dessa maneira, estudiosos do mundo todo vêm discutindo intensamente a substituição do PIB por um novo indicador que contemple o desenvolvimento sustentável e, a pardas variáveis econômicas, incorpore também as sociais e as ambientais. (MENEGUIN, [s.d.])

Assim, tal política encontra-se na contramão da efetivação dos direitos fundamentais pela via administrativa, bem como ainda parte de uma concepção desenvolvimentista do início do século XX, a despeito de toda a evolução social e constitucional nessa matéria.

O novo paradigma desenvolvimentista impõe a consideração de critérios de sustentabilidade social, ambiental e de viabilidade econômica. São as soluções que considerem esses três elementos, isto é, que promovam o crescimento econômico com impactos positivos em termos sociais e ambientais, que merecem destaque. Portanto, diante de uma ordem constitucional que não requer unicamente em retorno financeiro e passa a valorizar o desenvolvimento sustentável, é natural que surjam questionamentos e discussões sobre a mensuração desse novo paradigma.

A definição de um indicador para medir sustentabilidade é algo extremamente complexo, em torno do que não existe consenso. É importante também ter em mente que não adianta estabelecer uma fórmula ideal se não houver dados disponíveis para quantificá-la. Procurando adotar uma visão bem pragmática, os citados especialistas apresentam algumas recomendações para se refletir sobre uma medida de desenvolvimento sustentável.

Primeiramente, [...] uma avaliação de sustentabilidade difere de uma avaliação de felicidade da população. Os dois assuntos podem ser tratados de forma complementar, mas não necessariamente devem fazer parte de um único indicador. Sugerem também que, ao medir sustentabilidade, devem ser contabilizadas as mudanças dos estoques das variáveis que afetarão a capacidade das gerações futuras de terem atendidas suas necessidades, contabilizando-se não só os recursos naturais, mas também quantidades e qualidades humanas, sociais e econômicas. Alguns indicadores podem ser quantificados monetariamente, outros não, sendo necessária uma medida física. (MENEGUIN, [s.d.])

Ademais, quando se analisam as políticas, planos e programas, ficaram evidentes dois pontos: (i) a atuação é baseada nas regiões administrativas do IBGE, vinculando o papel de implementação a União, estados, territórios e/ou municípios; (ii) as regionalizações produzidas pelas políticas, planos ou programas dependem do seu "objeto".

Assim, é possível concluir que, especialmente a partir do governo de Luís Inácio Lula da Silva até o governo de Dilma Rousseff, houve um inédito esforço na concretização dos postulados constitucionais. Porém, por outro lado, a simples existência da política, plano ou programa garantia a eficácia, porém não a para dar respostas às demandas sociais e à promoção de direitos fundamentais, 
na prática ainda encontra-se imobilizado por sua falta de abertura à outras disciplinas e às dificuldades cotidianas do Administrador Público.

De fato, a definição de critérios de escolha de áreas prioritárias para atuação supostamente garantiria uma maior eficiência, com economia de recursos e a melhoria de integração na gestão nos diferentes níveis (federal, estadual e local). Porém há ainda a necessidade de melhoria no mapeamento e georreferenciamento das ações, ou seja, necessidade de espacialização das políticas públicas. "Como exemplo, os dados do PAC são divulgados como figuras, não representando mapas. Tal ação permitiria a análise integrada do planejamento federal, permitindo integração dos dados e verificação de possíveis incompatibilidades e sobreposições" (SILVA, 2013).

Portanto, não é possível uma leitura unitária tanto do direito, como um todo, quanto dos postulados constitucionais. Deve, então, o direito contribuir e orientar formuladores de políticas públicas e órgãos responsáveis pela coleta de dados a adaptarem seus procedimentos de forma a viabilizar a implementação de novos (e eficientes) indicadores no médio prazo.

A interdisciplinaridade aqui deve ser vista como estratégiaepistemológica. Neste sentido a interdisciplinaridade deve ser colocada ao serviço de uma concepção crítica do conhecimento, na linha do pragmatismo. É necessária a admissão que a ciência do direito, do direito constitucional e do direito administrativo, tal como as demais ciências, é parcial e incompleta. Bem por isso há uma necessidade de realizar uma leitura jurídica que rejeite a separação entre as cadeiras jurídicas tradicionais e as cadeiras auxiliares, e que englobe aos seus métodos tradicionais, os demais métodos plurais dos demais ramos do saber (tal como vem sendo feito, em maior medida, no tocante à compreensão do Direito Ambiental).

\section{CONCLUSÕES}

Tratou-se esta de uma pesquisa voltada à busca de soluções concretas, viabilizadas e conformadas pelo Direito, para que os cidadãos não necessitem esperar os muitos amanhãs prometidos e não cumpridos. As tarefas constitucionais impostas são urgentes.

Entendendo que a compreensão dos fundamentos e objetivos do Estado brasileiro permite a adequada compreensão e realização dos postulados constitucionais, procurou-se em um primeiro momento expressar os preceitos teóricos indispensáveis ao objeto de estudo que se propôs. Em primeiro lugar tratou de delinear as políticas públicas como processos juridicamente articulados, com complexidade não abrangida por visões desenvolvimentistas estruturalistas. Adiante, definiu o mínimo existencial como parâmetro impositivo a ser observado em suas formulações. E, por fim, demonstrou que o artigo 3 , da Constituição Federal, deve ser lido como "cláusula transformadora" da realidade brasileira, com a finalidade de superação do subdesenvolvimento, não somente econômico, mas político, cultural e social.

Por fim, demonstrou-se que embora os últimos governos federais tenham trazido mudanças significativas no tocante à implementação de direitos sociais, estas não foram capazes de modificar as "regiões de subdesenvolvimento interno", não sendo capazes, inclusive, de garantir o mínimo existencial para 
todos os seus cidadãos. Ademais, os planos de governo ainda não conformam o papel do Estado ao delineado pela Constituição, trazendo, em âmbito infralegal, o Estado ainda como subsidiário no que toca ao desenvolvimento das regiões. Demonstrou-se, ainda, que a Administração Pública tem dificuldade de implementar políticas públicas de desenvolvimento social em muito por sua racionalidade, mas também em muito por não tem indicadores precisos de avaliação e planejamento de tais políticas. 


\section{REFERENCIAS}

ABRUCIO, Fernando Luiz. A coordenação federativa no Brasil: a experiência do período FHC e os desafios do governo Lula. Revista de Sociologia e Política, n. 24, jun./2005.

AGUILAR VILLANUEVA, Luis F. La hechura de las políticas. México: Porrúa, 1992.

ARRETCHE, Marta. Trazendo o conceito de cidadania de volta. In:

Trajetória das desigualdades: como o Brasil mudou nos últimos cinquenta anos. São Paulo: Editora Unesp, 2015.

BARCELLOS, Ana Paula de. A eficácia jurídica dos princípios constitucionais: 0 princípio da dignidade da pessoa humana. 3 ed. Rio de Janeiro: Renovar, 2011.

BARROSO, Luís Roberto. A dignidade da pessoa humana no direito constitucional contemporâneo: a construção de um conceito jurídico à luz da jurisprudência mundial. Belo Horizonte: Editora Fórum, 2012.

BARROSO, Luís Roberto. Curso de direito constitucional contemporâneo: os conceitos fundamentais e a construção do novo modelo. 2.ed. São Paulo: Saraiva, 2009.

BARROSO, Luís Roberto. Da falta de efetividade à judicialização excessiva: direito à saúde, fornecimento gratuito de medicamentos e parâmetros para a atuação judicial. Interesse Público IP, Belo Horizonte, n. 46, ano 9, nov./dez. 2007.

BARROSO, Luís Roberto; BARCELLOS, Ana Paula de. O começo da História: a nova interpretação constitucional e o papel dos princípios no Direito brasileiro. In: BARROSO, Luís Roberto (Org.). A nova interpretação constitucional: ponderação, direitos fundamentais e relações privadas. 3a ed. Rio de Janeiro: Renovar, 2008.

BERCOVICI, Gilberto. Constituição e superação de desigualdades regionais. In: GRAU, Eros Roberto; GUERRA FILHO, Willis Santiago (Org.). Direito constitucional: estudos em homenagem a Paulo Bonavides. São Paulo: Malheiros, 2001.

BERCOVICl, Gilberto. Constituição econômica e desenvolvimento: uma leitura a partir da Constituição de 1988. São Paulo: Malheiros, 2005.

BERCOVICl, Gilberto. Desigualdades regionais, Estado e Constituição. São Paulo: 
BERCOVICI, Gilberto. O federalismo no Brasil e os limites da competência legislativa e administrativa: memórias da pesquisa. Revista Jurídica, Brasília, vol. 10, ed. especial, p. 01-18, abr./mai. 2008.

BONAVIDES, Paulo. A constituição aberta. Belo Horizonte, MG: Del Rey, 1993.

BRASIL. Ministério do Desenvolvimento Social e Combate à Fome. O Brasil sem miséria. Organizadores: Tereza Campello, Tiago Falcão, Patrícia Vieira da Costa. Brasília: MDS, 2014.

BRITTO, Carlos Ayres. O humanismo como categoria constitucional. Belo Horizonte: Fórum, 2012.

BUCCl, Maria Paula Dallari. O conceito de política pública em Direito. In. (Org.). Políticas públicas: reflexões sobre o conceito jurídico. São Paulo: Saraiva, 2006.

CASIMIRO, Lígia Maria Silva Melo de. 20 anos de Constituição: uma análise sobre o dever de planejar e executar políticas públicas para cidades sustentáveis. A\&CRevista de Direito Administrativo e Constitucional, Belo Horizonte, ano 8, n. 34, out./dez. 2008.

CLÈVE, Clèmerson Merlin. Para uma dogmática constitucional emancipatória. Belo Horizonte: Fórum, 2012.

COUTO, Cláudio Gonçalves. Constituição, competição e políticas públicas. Lua Nova, São Paulo, n. 65, p. 95-135, ago. 2005.

DWORKIN, Ronald. Taking rights seriously. Cambridge: Harvard University Press, 1978.

FACHIN, Melina Girardi. Direitos humanos e desenvolvimento. Rio de Janeiro: Renovar, 2015.

FRANCO, Caroline da Rocha; Montemezzo, Francielle Pasternak. O lobby e as políticas públicas: a atuação do mercado na definição da agenda governamental brasileira. In: SALGADO, Eneida Desiree; GABARGO, Emerson (Orgs). Direito, mercantilização e justiça. Curitiba: Editora UFPR, 2016. p. 103.

FREITAS, Juarez. Sustentabilidade: direito ao futuro. 2 ed. Belo Horizonte: Fórum, 
FURTADO, Celso. Formação econômica do Brasil. 34. ed. São Paulo: Companhia das Letras, 2007.

GABARDO, Emerson. Interesse público e subsidiariedade: o Estado e a sociedade civil para além do bem e do mal. Belo Horizonte: Fórum, 2009.

HACHEM, Daniel Wunder. A noção constitucional de desenvolvimento para além do viés econômico: reflexos sobre algumas tendências do Direito Público brasileiro. A\&C - Revista deDireito Administrativo \& Constitucional, Belo Horizonte, ano 13, n. 53, p. 133168, jul./set. 2013.

HACHEM, Daniel Wunder. Tutela administrativa efetiva dos direitos fundamentais sociais: por uma implementação espontânea, integral e igualitária. 2014. 614 p. Tese (doutorado) - Universidade Federal do Paraná, Setor de Ciências Jurídicas, Programa de Pós-Graduação em Direito. Defesa: Curitiba, 24/02/2014. p. 6.

JUSTEN FILHO, Marçal. Parecer fornecido ao Ministério das Cidades sobre a minuta de anteprojeto da Lei da Política Nacional de Saneamento Básico. 2005. Disponível em < http://www.planalto.gov.br/ccivil_03/revista/Rev_72/pareceres/saneamento_co mplementar_MarcalJustenFilho_1.pdf>. Acesso em: 28 dez. 2015.

KRELL, Andreas J. A necessária mudança de foco na implementação do Federalismo Cooperativo no Brasil: da definição de competências legislativas para o desenho de formas conjuntas de execução Administrativa. In: SOUZA NETO, Cláudio Pereira de; SARMENTO, Daniel; BINENBOJM, Gustavo (Org.). Vinte anos da Constituição Federal de 1988. Rio de Janeiro: Lumen Juris, 2009.

LEHMAN, Jeffrey; PHELPS, Shirelle.West's Encyclopedia of American Law. 2 ed. The Gale Group, Inc., 2008. Disponível em:<http://legaldictionary.thefreedictionary.com/Public+Policy>. Acesso em 23 set. 2016.

LENCIONI, SANDRA. A mudança do discurso desenvolvimentista face à crise da economia: a falência das políticas de desenvolvimento social. Revista do Departamento de Geografia da Faculdade de Filosofia, Letras e Ciências Humanas da Universidade de São Paulo, São Paulo, vol. 6, p. 83-89, 1992.

LOBATO, Monteiro. Urupês. In: . Urupês. São Paulo: Globo, 2007. 
MATTEO, Miguel [et. al.]. O Brasil em perspectiva territorial: regionalizações como uma estratégia do desenvolvimento emergente. In: INSTITUTO DE PESQUISA ECONOMICA APLICADA. Brasil em desenvolvimento: estado, planejamento e políticas públicas. Brasília: Ipea, 2013.

MELLO, Celso Antônio Bandeira de. Discricionariedade e controle jurisdicional. 2. ed. São Paulo: Malheiros, 1993.

MENEGUIN, Fernando. Como construir um Indicador de Desenvolvimento Sustentável?. Disponível em: <http://www.brasil-economiagoverno.org.br/2013/02/25/como-construir-um-indicador-de-desenvolvimentosustentavel/>.

MIRANDA, Jorge. Apreciação pelo Partido Popular Democrático (PPD) dos Projetos de Constituição e das Propostas de Sistematização durante o Processo Constituinte Português de 1976. Disponível em < http://app.parlamento.pt/LivrosOnLine/Vozes_Constituinte/med01000166j.html> . Acesso em 25 abr. 2016.

MIRANDA, Pontes de. Direitos à subsistência e direito ao trabalho. Rio de Janeiro: Ed. Alba Limitada, 1933.

NALINI, José Renato. Funéreos Círios Federais. In: RAMOS, DircêoTorrecillas (Org.). O federalista atual: teoria do federalismo. Belo Horizonte, Arraes Editores, 2013.

NASCIMENTO, Alexandre Ferreira do. A política pública como campo multidisciplinar. Marques E, Faria CAP, organizadores. São Paulo: Editora Unesp/Rio de Janeiro: Editora Fiocruz; 2013. Cad. Saúde Pública. 2014, vol.30, n.4.

NERI, Marcelo. Primeiros impactos do novo federalismo social. Revista Conjuntura Econômica, v. 66, n. 1, jan./2012.

OLIVEIRA, Gustavo Justino de. Direito ao desenvolvimento da Constituição brasileira de 1988. Revista Eletrônica de Direito Administrativo Econômico, Salvador, n. 16, dez. 2009.

PALOTTI, Pedro Lucas de Moura; MACHADO, José Angelo. Coordenação Federativa e a "Armadilha da Decisão Conjunta": As Comissões de Articulação intergovernamental das políticas sociais no Brasil. DADOS - Revista de Ciências Sociais, Rio de Janeiro, vol 57, n. 2, 2014. 
PARADA, Eugenio Lahera. Política y políticas públicas. In: FERRAREZI, Elisabete; ARAVIA, Enrique (Orgs.). Políticaspúblicas.vol. 1. Brasília: Enap, 2006.

PROGRAMA DAS NAÇÕES UNIDAS PARA O DESENVOLVIMENTO. Transformando Nosso Mundo: A Agenda 2030 para o Desenvolvimento Sustentável.<http://www.undp.org/content/dam/brazil/docs/agenda2030/undpbr-Agenda2030-completo-pt-br-2016.pdf>. Acesso em: 23 fev. 2016.

RAWLS, John. PoliticalLiberalism. New York. Columbia University Press, 2005.

ROSANVALLON, Pierre. A nova questão social: repensando o Estado Providência. Brasília: Instituto Teotônio Vilela, 1998.

SANTOS, Milton. O Brasil: território e sociedade no início do século XXI. São Paulo: Record, 2008.

SARAVIA, Enrique. Introdução à teoria da política pública. In: SARAVIA, Enrique; FERRAREZI, Elisabete (Org.). Políticas Públicas - Coletânea.vol. 1. Escola Nacional de Administração Pública- ENAP, 2006.

SARLET, Ingo Wolfgang. A eficácia dos direitos fundamentais: uma teoria geral dos direitos fundamentais na perspectiva constitucional. 11. ed. rev. e atual. Porto Alegre: Livraria do Advogado, 2012.

SARMENTO, Daniel. Dignidade da pessoa humana: conteúdos, trajetória e metodologia. Belo Horizonte: Fórum, 2016.

SEN, Amartya. Desenvolvimento como liberdade. São Paulo: Companhia das Letras, 2000.

SILVA, Sandro Pereira. Considerações analíticas e operacionais sobre a abordagem territorial em políticas públicas. In: INSTITUTO DE PESQUISA ECONOMICA APLICADA. Brasil em desenvolvimento: estado, planejamento e políticas públicas. Brasília: Ipea, 2013.

SILVEIRA, Alessandra. A cooperação intergovenamental no Estado composto brasileiro: análise jurídico-constitucional. In: VII Congreso Internacional del CLAD sobre la reforma del Estado y de la Administración Pública, Lisboa, Portugal, out. 2002. 
SOUZA, Claudia Beeck Moreira de; COSTA, Tailaine Costa. Libertarismo, felicidade e justiça.In: GABARDO, Emerson; SALGADO, Eneida Desiree. Direito, liberdade e justiça. Belo Horizonte: Fórum, 2014.

TAVARES, André Ramos. O federalismo social. RAMOS, DircêoTorrecillas (Org.). 0 federalista atual: teoria do federalismo. Belo Horizonte, Arraes Editores, 2013.

TORRES, Ricardo Lobo. A jusfundamentalidade dos direitos sociais. Revista de Direito da Associação dos Procuradores do Novo Estado do Rio de Janeiro, Rio de Janeiro, v. 12, p. 349374,2003.

TORRES, Ricardo Lobo. A ideia de liberdade no estado patrimonial e no estado fiscal. Rio de Janeiro: Renovar, 1991.

TORRES, Ricardo Lobo. Tratado de direito constitucional financeiro e tributário, volume V: o orçamento na constituição. 3.ed. Rio de Janeiro: Renovar, 2008.

VALLE, Vanice Regina Lírio do. Políticas públicas, direitos fundamentais e controle judicial. Belo Horizonte: Fórum, 2009.

WEBER, Thadeu. A ideia de um "mínimo existencial" de J. Rawls. Kriterion, Belo Horizonte, v. 54, n. 127, p. 197-210, jun. 2013.

ZANETI JR., Hermes. A teoria da separação de poderes e o Estado democrático co nstitucional. Revista Brasileira de Direito Processual -

RBDPro, Belo Horizonte, ano 18, n. 70, abr./jun. 2010.

Recebido: 19 abr. 2017

Aprovado: 01 jul. 2017.

DOI: $10.3895 /$ rbpd.v6n3.5694

Como citar: BARON DE VARGAS, T. Ainda faz sentido discutir políticas públicas sob a perspectiva das regiões? Os desafios do Plano "Brasil sem Miséria". R. bras. Planej. Desenv.,Curitiba v. 6, n. 3, p. 388-426,

set./dez. 2017. Disponível em: <https://periodicos.utfpr.edu.br/rbpd>. Acesso em: XXX.

Correspondência:

Tuany Baron de Vargas

Estados Unidos 1168 | C1101AAX | Ciudad de Buenos Aires, Argentina

Direito autoral: Este artigo está licenciado sob os termos da Licença CreativeCommons-Atribuição 4.0

Internacional. 